\title{
Change in the size of Walker Lake during the past 5000 years
}

\author{
L. V. Benson ${ }^{\mathrm{a}}$, P. A. Meyers ${ }^{\mathrm{b}}$ and R. J. Spencer ${ }^{\mathrm{c}}$ \\ ${ }^{a}$ U.S. Geological Survey, National Center for Atmospheric Research, Boulder, CO 80307, USA \\ ${ }^{\mathrm{b}}$ Department of Geological Sciences, University of Michigan, Ann Arbor, MI 48109, USA \\ 'Department of Geology and Geophysics, The University of Calgary, Calgary, T2N IN4; Canada
}

(Received and accepted June 27, 1990)

\begin{abstract}
Benson, L. V., Meyers, P. A. and Spencer, R. J., 1991. Change in the size of Walker Lake during the past 5000 years. Palaeogeogr., Palaeoclimatol., Palaeoecol., 81: 189-214.

In 1984, a 12-m sediment core (WLC84-8) was taken from the deepest part of Walker Lake. Samples of the core were analysed for diatoms, pollen, carbonate mineralogy, magnesium content, $\delta^{18} \mathrm{O}$ and $\delta^{13} \mathrm{C}$ values of the total inorganic fraction, $\delta^{18} \mathrm{O}$ and $\delta^{13} \mathrm{C}$ values of Limnocythere ceriotuberosa, $\delta^{13} \mathrm{C}$ values of the total organic fraction, grain size, and magnetic susceptibility. The data indicate that Walker Lake became shallow and probably desiccated between $\geqslant 5300-4800$ and $2700-$ 2100 yr B.P. Each of the organic and inorganic proxy indicators of lake size discussed in this paper was useful in determining the presence of the shallow-lake intervals. However, none of the indicators was useful in determining the cause of the shallowlake intervals. Instead, the types of fish living in Walker Lake prior to 1940 were used to demonstrate that shallow-lake intervals resulted from diversion of the Walker River and not from climatic aridity. Major changes in mineralogy and magnesium content of carbonates and major changes in diatom populations with time were found to be a function of the chemical evolution of Walker Lake combined with changing lake size. The stable isotopes of oxygen and carbon were found to be good indicators of lake volume changes. A lake-level record for Walker Lake constructed from stable-isotope data was found to be similar to a lake-level record constructed using tufa and tree-stump data. Both records indicate relatively high lake levels between $4800-2700$ yr B.P., at $1250 \mathrm{yr}$ B.P., and within the last $300 \mathrm{yr}$. Substantial declines in lake level occurred $\sim 2000$ and $\sim 1000 \mathrm{yr}$ B.P.
\end{abstract}

\section{Introduction}

The Walker Lake subbasin, one of seven topographic depressions comprising the Lahontan basin (Fig.1), is located in northeastern California and west-central Nevada (Fig.2). During the Pleistocene, large lakes occupied the Lahontan basin (Benson and Thompson, 1987a; Lao and Benson, 1988). The Walker Lake subbasin is relatively small and steepsided compared to most other Lahontan subbasins; it is separated from the Carson Desert subbasin by a sill with a maximum altitude of $1308 \mathrm{~m}$ located in Adrian Valley (Benson and Mifflin, 1986) (Fig.2). Walker Lake exceeds still level and spills to the Carson Desert subbasin when its surface area increases to $\sim 3.5 \times$ its mean-historical value.

Since the initial study of Russell (1885), it has been postulated that the history of Walker Lake may have been affected by diversion of the Walker River into the Carson River through Adrian Valley (Fig.2) (King, 1978; Davis, 1982). King (1978) claims to have found geomorphic evidence for diversion of the Walker River; however, the sedimentological record left by the postulated diversion remains undated. In this paper, a variety of lake-size indicators are compared and used to determine the fluctuation history of Walker Lake for the past $5000 \mathrm{yr}$. The Walker Lake record surface-altitude and surface-area records are then compared with the late-Holocene surface-area record of Mono Lake.

\section{Methods}

Walker Lake was cored in July of 1984 from a barge anchored $\sim 2.6 \mathrm{~km}$ off the western shore of Walker Lake in $34 \mathrm{~m}$ of water (Fig.3). Shallow 


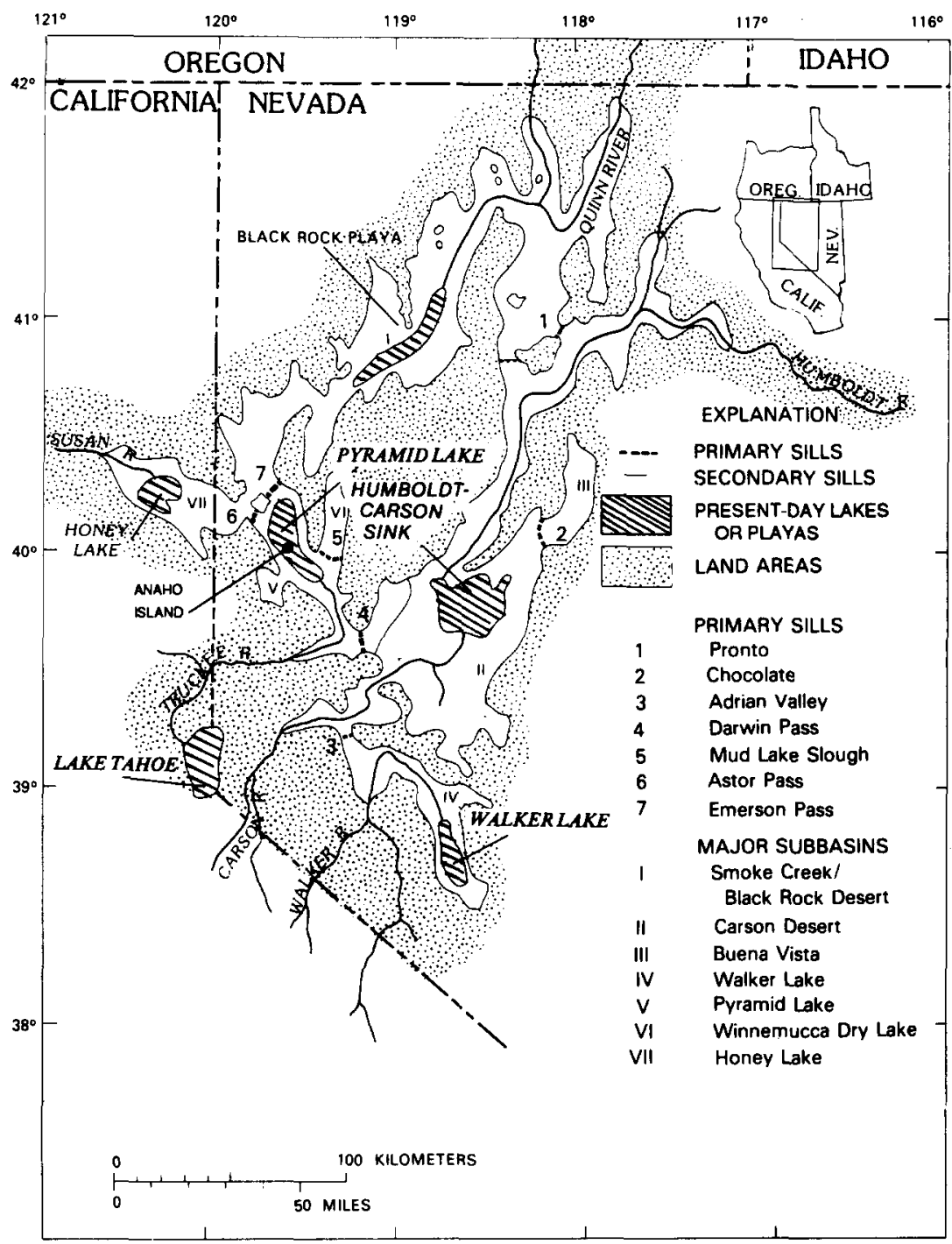

Fig. 1. Surface area of Lake Lahontan about 14,500 yr B.P.

sediment cores (WLC84-6 and 7) were taken with a piston-fitted, 5-cm interior diameter, 3-m long, clear-polycarbonate tube (Bradbury, 1987). A deeper core (WLC84-8) was taken with a 5 -cm diameter, square-rod Livingstone piston sampler. Coring of the 12-m WLC84-8 core was accomplished manually by forcing the drill stem and coring tubes into the sediment. The drill stem and tubes were raised to the surface by using a winch mounted on a Mobile B-6 $1^{1}$ drilling rig.

\footnotetext{
${ }^{1}$ Use of tradenames in this report is for descriptive purposes only and does not imply endorsement by the U.S. Geological Survey.
}

Rotary coring using a wireline drilling rig also was attempted at two sites (Fig.3) (Benson, 1988). Six Phleger gravity cores ranging in length from 0.77 to $1.80 \mathrm{~m}$ and one $4.50-\mathrm{m}$ Mackereth core were taken in 1975 and 1976 (Fig.3) (Benson and Spencer, 1983).

The amounts and magnesium contents of carbonate minerals were estimated by $\mathrm{x}$-ray diffraction (Goldsmith and Graf, 1958). Uncertainties using this method are about \pm 2 mole $\% \mathrm{MgCO}_{3}$. Samples of calcite-ostracode valves for $\delta^{18} \mathrm{O}$ and $\delta^{13} \mathrm{C}$ isotope analysis were selected from core WLC848 by Richard Forester of the U.S. Geological 


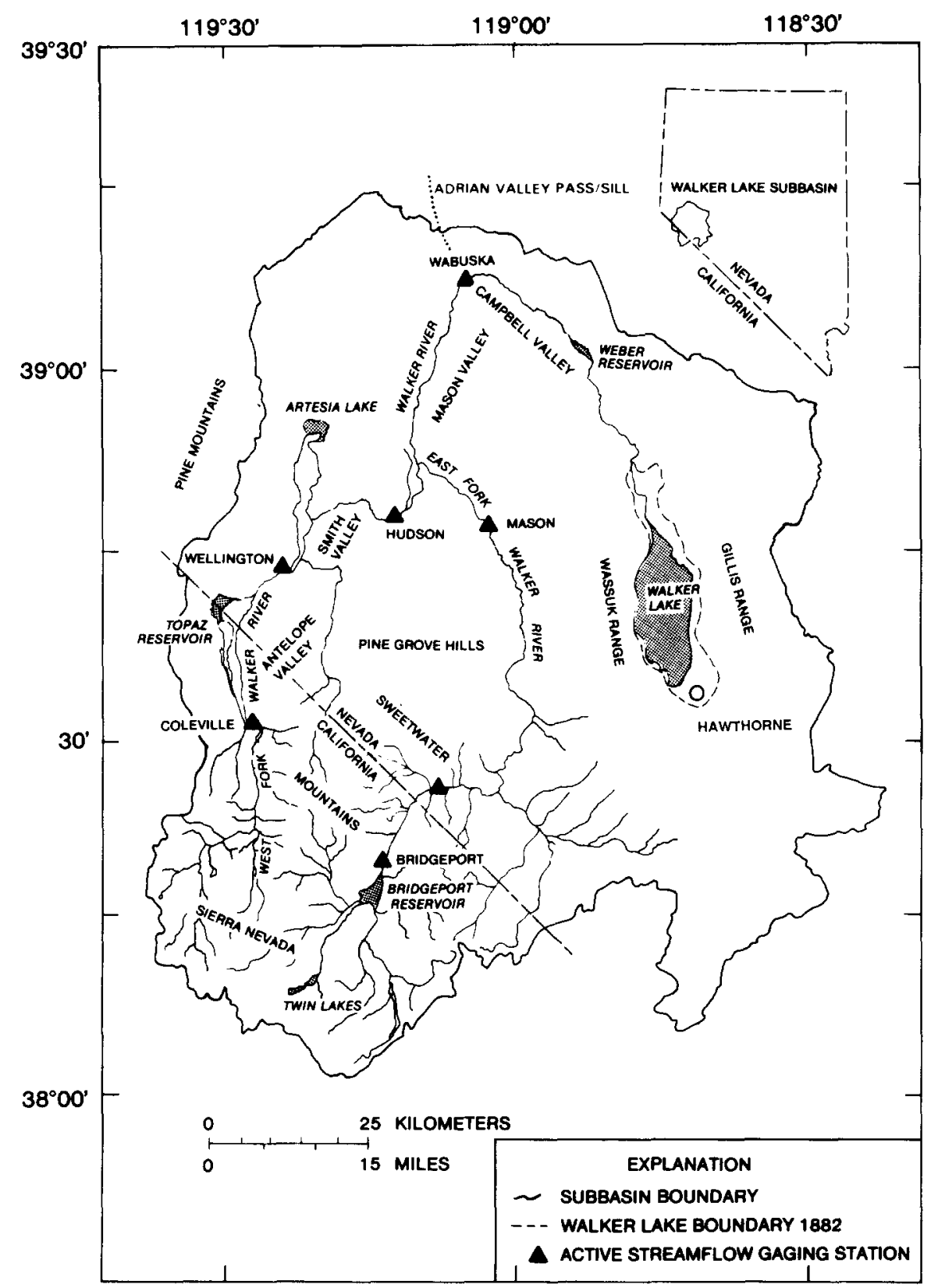

Fig.2. Drainage area of the Walker Lake subbasin.

Survey. A series of tests was performed to determine the minimum number of ostracode valves that would yield reproducible amounts of $\delta^{18} \mathrm{O}$ and $\delta^{13} \mathrm{C}$. For the small ostracodes (Limnocythere ceriotuberosa) commonly found in WLC84-8, as few as 10 valves were found to yield consistent results; however, 15-50 valves usually were analysed. Analayses of ostracode samples that pro- duced transducer pressures $<0.5 \mathrm{mb}$ are not included in this report. Magnetic-susceptibility measurements were made before the cores were subsampled. Reproducible susceptibility variations were obtained on all three cores (Fig.4). Downcore distributions of the various proxy indicators of lake-size change were compared by overlaying $20 \times 25 \mathrm{~cm}$ transparencies of the data records. 


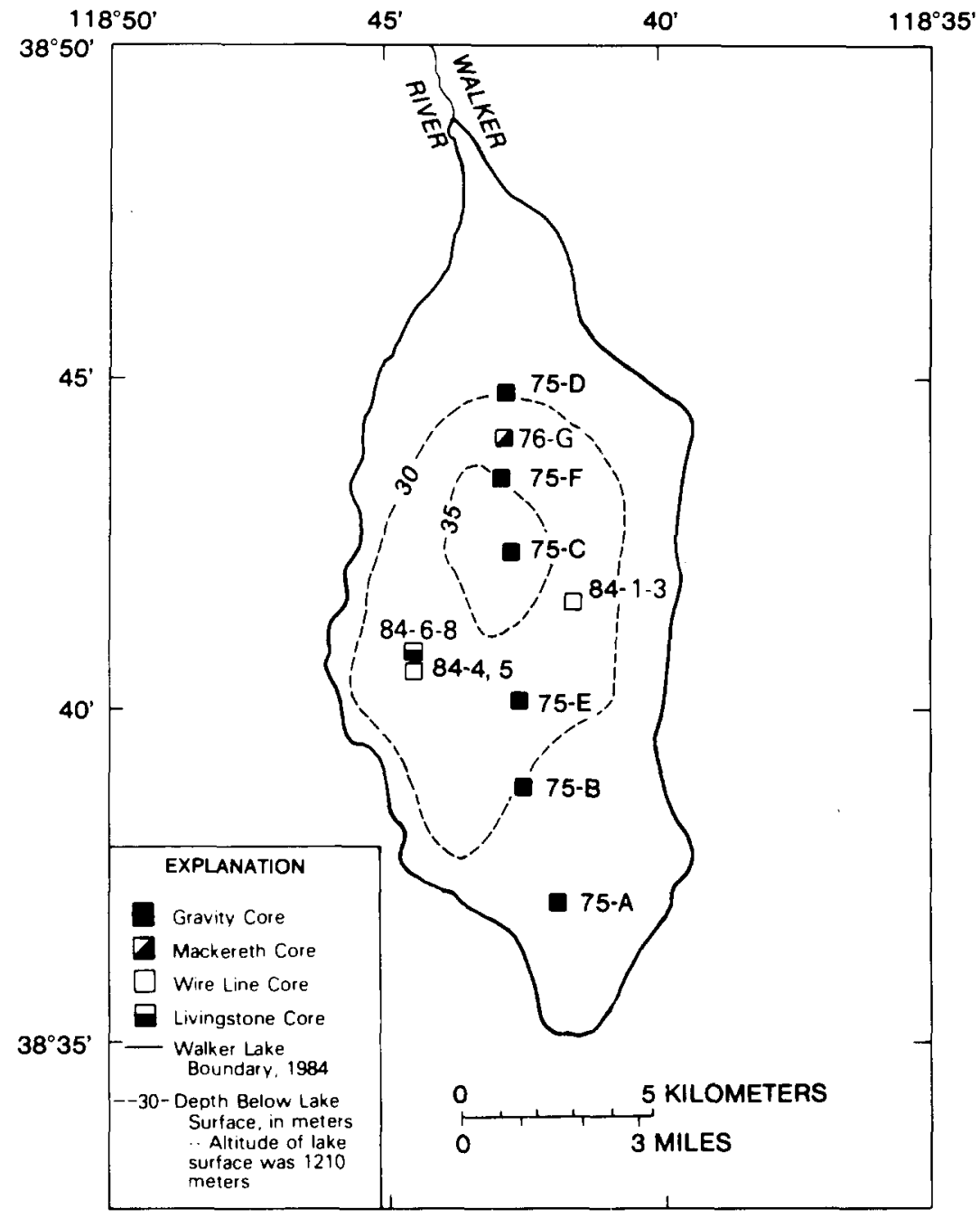

Fig.3. Locations of offshore cores collected by Walker Lake (prefix WLC omitted from core number).

All chemical distribution-of-species calculations were made using WATEQF (Plummer et al., 1976). Mean-annual inputs of dissolved solids from the Walker River were calculated by plotting the dailymole fluxes (mmoles/day) of chemical constituents as a function of mean-daily discharges (L/day) (Fig.5) for the Wabuska gaging site (Fig.2) (U.S. Geological Survey, 1960, 1963, and 1961-1987). Linear regressions between these two variables were performed over two discharge intervals: $0.0-0.4 \times 10^{9} \mathrm{~L} /$ day and $0.4-5.2 \times 10^{9} \mathrm{~L} /$ day. Discharge data from the Walker River were subdivided into 34 class intervals for the years 1940-1987
(16,801 observations). The regressions equations were used to associate the midpoint of each of the 34 flow intervals with a mole flux for each chemical constituent. The average number of days in a year spent in each flow interval was multiplied by the mole flux associated with that interval and the results for all 34 intervals summed to obtain the mean-annual input of each chemical constituent. Summation of positively and negatively charged chemical constituents for the discharge-weighted flux indicated $49.2 \times 10^{10} \mathrm{meq} /$ day of positive charges and $48.2 \times 10^{10} \mathrm{meq} /$ day of negative charges. 


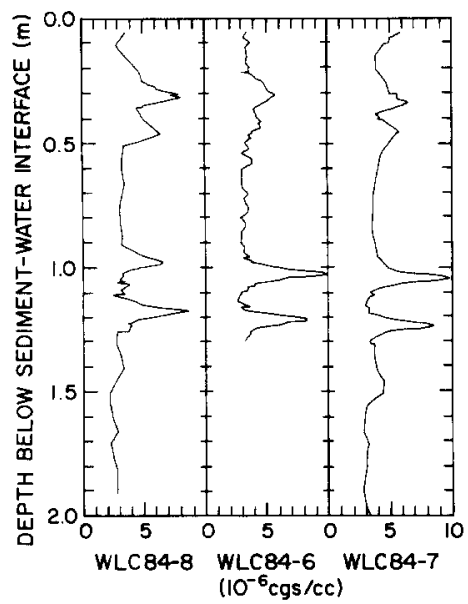

Fig.4. Magnetic-susceptibility data for upper $2 \mathrm{~m}$ of WLC848,6 , and 7 (W. Witte, pers. comm., 1990).

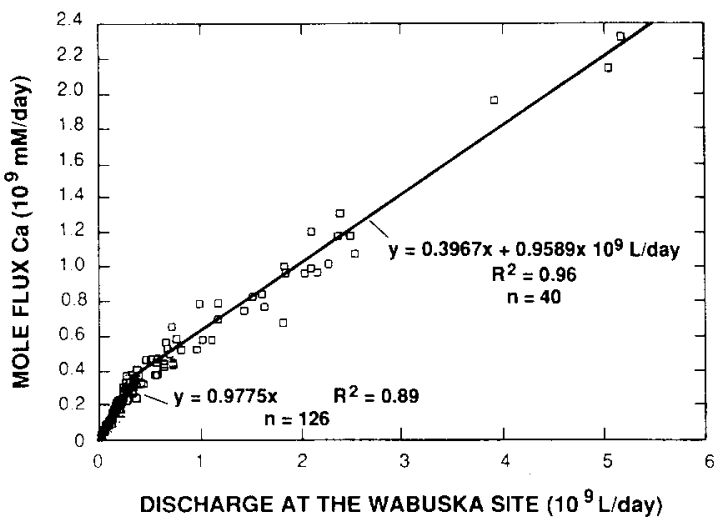

Fig.5. Mass flux of dissolved calcium shown as a function of discharge of the Walker River at the Wabuska site.

\section{Historic record of change in the hydrologic balance of the Walker Lake subbasin}

The principal source of water to the Walker Lake subbasin is the Walker River, which has a diversion-corrected mean-annual discharge of about $0.38 \mathrm{~km}^{3}$ (Benson and Thompson, 1987b). Mean-annual precipitation is $0.13 \mathrm{~m}$ at Hawthorne, Nevada, (Fig.2) and mean-annual evaporation is about $1.35 \mathrm{~m}$ (Milne, 1987). Consumptive use of water for crops and domestic purposes has altered the natural water balance of the Walker subbasin. Irrigated lands in 1989 totaled between 300 and $500 \mathrm{~km}^{2}$. Synchronous discharge measurements at major streamflow-gaging stations (Fig.2) indicate that losses during 1958 to 1974 averaged about $0.23 \mathrm{~km}^{3} / \mathrm{yr}$, or about $60 \%$ of the total input to Walker Lake (Benson and Leach, 1979). As a result of this loss of potential discharge, Walker Lake has decreased in depth by about $50 \%$, in surface area by about $50 \%$, and in volume by about 70\% since 1870 (Harding, 1965; U.S. Geol. Surv., 1960, 1963, 1961-1987). Milne's (1987) reconstruction of the pristine lake-level record for Walker Lake (Fig.6) indicates that the lake would have maintained a mean elevation of $1253 \pm 3 \mathrm{~m}$ from 1872 to 1988 .

\section{Proxy indicators of change in the hydrologic balance of the Walker Lake subbasin for the past 5000 years}

\section{Diatoms in WLC84-8 and WLC76-G}

Bradbury's (1987) analysis of diatom types and concentrations preserved in WLC84-8 and WLC76-G (Fig.3) indicated that a regular progression of species abundances existed in both cores (Fig.7). Bradbury (1987) recognized two intervals in WLC84-8 (Fig.7a; 12.0-10.9 $\mathrm{m}$ and 4.6-3.8 $\mathrm{m}$ ) and one interval in WLC76-G (3.8-2.5 $\mathrm{m})$ characterized by low abundances of diatoms. He was able to correlate the upper $4.6-3.8 \mathrm{~m}$ interval in WLC84-8 with the $3.8-2.5 \mathrm{~m}$ interval near the base of WLC76-G using a Mono Crater volcanic ash and the top of the Stephanodiscus diatom zone. The low-diatom concentration intervals in WLC84-8 contain a euryhaline Navicula species (Fig.7b). (Bradbury (1987) used both these criteria to suggest that Walker Lake was very shallow and perhaps desiccated during the 12.0$10.9 \mathrm{~m}$ and $4.6-3.8 \mathrm{~m}$ depth intervals.

Abundances of seven diatom species with reasonably well known salinity tolerances are shown in Fig.7. The relatively rapid transition from high salinity to dilute conditions, represented by the disappearance of Navicula and the sequential appearance of Cyclotella meneghiniana and Stephanodiscus niagarae, probably resulted from mixing of residual lake brine with dilute Walker River discharge. The evidence for very dilute conditions, represented by the presence of Cyclotella ocellata (Fig.7d), may indicate: (1) the absence of residual brine, (2) a rapid increase in lake volume due to 


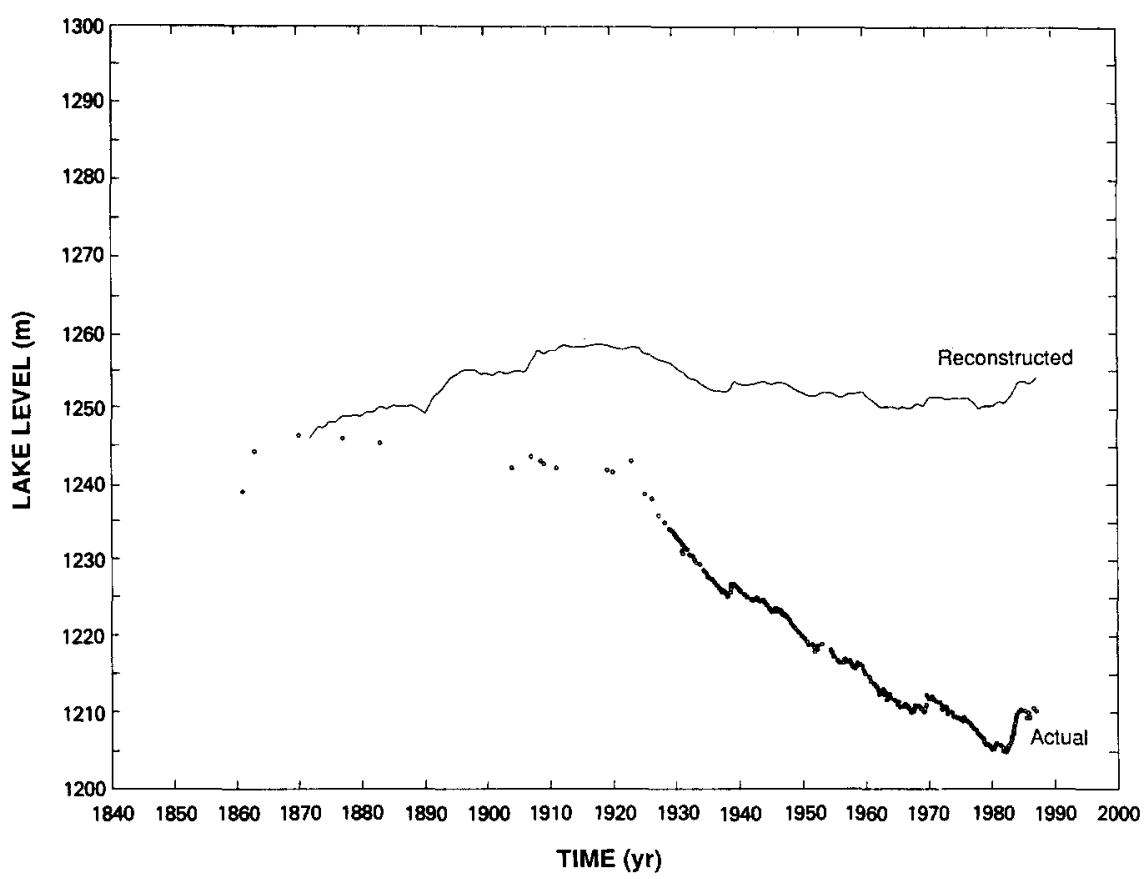

Fig.6. Reconstructed and actual (measured) levels of Walker Lake (adapted from Milne, 1987). Walker Lake levels were reconstructed by correcting the annual discharge of the Walker River for consumptive use. The surface area of Walker Lake was then recomputed on an annual basis and the mean annual evaporation rate applied to this surface area. Data from Benson and Mifflin (1986) were used to calculate lake level from recomputed annual surface areas.

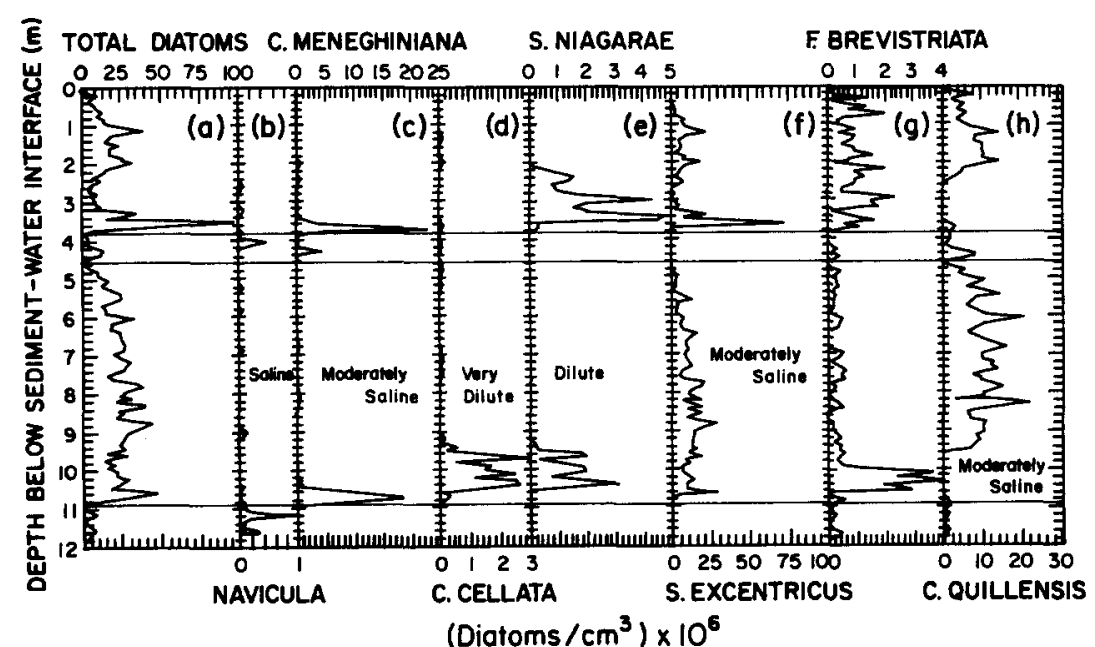

Fig.7. Abundances of selected diatoms from WLC84-8 (adapted from Bradbury, 1987). Diatoms, starting with Navicula have been arranged in order of abundance starting at the base of WLC84-8. Solid horizontal lines between 12.0-10.9 and 4.6-3.8 $\mathrm{m}$ in this and all subsequent figures indicate shallow lake (desiccation) intervals. Complete diatom names are given in text.

very large inputs of dilute discharge, or (3) that soluble salts, which had formed during the shallowlake phase, had been sealed by a low-permeability layer of salt or sediment before the subsequent increase or reintroduction of streamflow discharge.
The transition from dilute to moderately saline conditions indicated by the sequential appearance of Stephanodiscus excentricus and Cyclotella quillensis (Fig.7f and h) may indicate evaporative concentration of dissolved solids within a constant 
volume lake or it may indicate evaportive concentration of dissolved solids within a lake that was decreasing in volume due to increasing climatic aridity. For example, if we assume that Walker Lake achieved its present-day dissolved solids content of $1.15 \times 10^{12}$ moles $\left(3.76 \times 10^{13} \mathrm{~g}\right)$ in a linear manner over the past $2100 \mathrm{yr}$, then the concentration of a constant volume Walker Lake would have increased by $\sim 0.15$ millimoles $(5.0 \mathrm{mg})$ per yr. If diatom concentrations are to be unequivocally linked with changes in lake size, the linkage will have to be accomplished through an understanding of the relation of second-order changes in species concentration to changes in lake size. For example, the two troughs in the S. niagarae distributions (Fig.7e) may indicate moderately saline conditions associated with brief declines in lake level.

Fragilaria brevistriata is a benthic freshwater diatom fround near the mouth of the Walker River and in upstream habitats (Bradbury, 1987). Its presence between 10.7 and $9.9 \mathrm{~m}$ in WLC84-8 (Fig.7g) indicates very dilute conditions, which is consistent with peaks in the C.ocellata and $S$. niagarae populations (Fig.7d,e). Its association with $S$. niagarae between 3.7 and $2.2 \mathrm{~m}$ also indicates dilute conditions. However, its association with moderately saline $C$.quillensis between 2.2 and $0.2 \mathrm{~m}$ is more difficult to explain. It is suggested that $F$. brevistriata may have been transported from its shallow, freshwater-riverine habitat to the deepwater WLC84-8 site by extreme discharge events (floods) that scoured the channel and mouth of the Walker River.

\section{Radiocarbon ages of shallow-lake intervals}

Radiocarbon ages of the total organic carbon (TOC) fraction of six samples from WLC84-8 (Benson, 1988; Yang, 1988) are plotted in Fig.8a as a function of depth below the sediment-water interface. Radiocarbon ages of the TIC fraction were not plotted because certain carbonate minerals did not maintain a closed system after precipitation; i.e., metastable monohydrocalcite recrystallized to low-magnesium calcite (see p. 198). Linear fits to the age-depth data (Fig.8a) indicate that the lower shallow-lake interval began prior to $5300 \mathrm{yr}$ B.P. and ended $4800 \mathrm{yr}$ B.P. The upper shallow-lake interval began $2700 \mathrm{yr}$ B.P. and ended 2100 yr B.P.

Radiocarbon ages of 11 tufas and one rooted tree stump (Benson and Thompson, 1987a) (Table 1) are plotted in Fig. $8 \mathrm{~b}$ as a function of equivalent depth below the sediment-water interface. Radiocarbon ages of late Holocene tufas were not corrected for dilution by dead carbon. Calculations using the gas-exchange data of Peng and Broecker (1980) indicate that radiocarbon ages of materials precipitated from late-Holocene Walker Lake may be as much as $200 \mathrm{yr}$ too old. The uncorrected radiocarbon-age data indicate the presence of a relatively deep lake between 4500 3000 yr B.P. (9.9-5.4 m), a relatively shallow lake between $2200-1500 \mathrm{yr}$ B.P. $(4.0-3.3 \mathrm{~m})$, a relatively deep lake at $1250 \mathrm{yr}$ B.P. $(3.0 \mathrm{~m})$, a shallow lake at $1000 \mathrm{yr}$ B.P. $(2.3 \mathrm{~m})$, and a relatively deep lake between $840 \mathrm{yr}$ B.P. and $1850(2.0-0.3 \mathrm{~m})$ (the reconstructed mean historical altitude of Walker Lake is $1253 \mathrm{~m}$; Milne, 1987).

Tufa data for the time of the lower (older) part of the upper shallow-lake interval and the time of the entire lower shallow-lake interval do not exist. The absence of tufa data does not prove, but is consistent with the existence of very shallow lakes or playas in the Walker Lake subbasin at these times.

\section{Pollen in WLC84-8}

The distributions of major plant types in the Walker subbasin and surrounding areas are shown in Fig.9. Pollen assemblages from the modern surface sediments of Walker Lake are dominated by pine (Pinus), sagebrush (Artemisia), and other relatively mesic types, which were presumably transported from higher elevations by the Walker River. During past times of low streamflow discharge, or when the Walker River ceased to flow into Walker Lake, pollen from these mesic types declined in abundance while the abundance of pollen types from the local desert vegetation increased. Most notably, sedimentary intervals with elevated abundances of greasewood (Sarcobatus) pollen (11.9-10.8 and 4.2-3.5 m; Fig.10) (R. Thompson, pers. comm., 1990) indicate periods of 

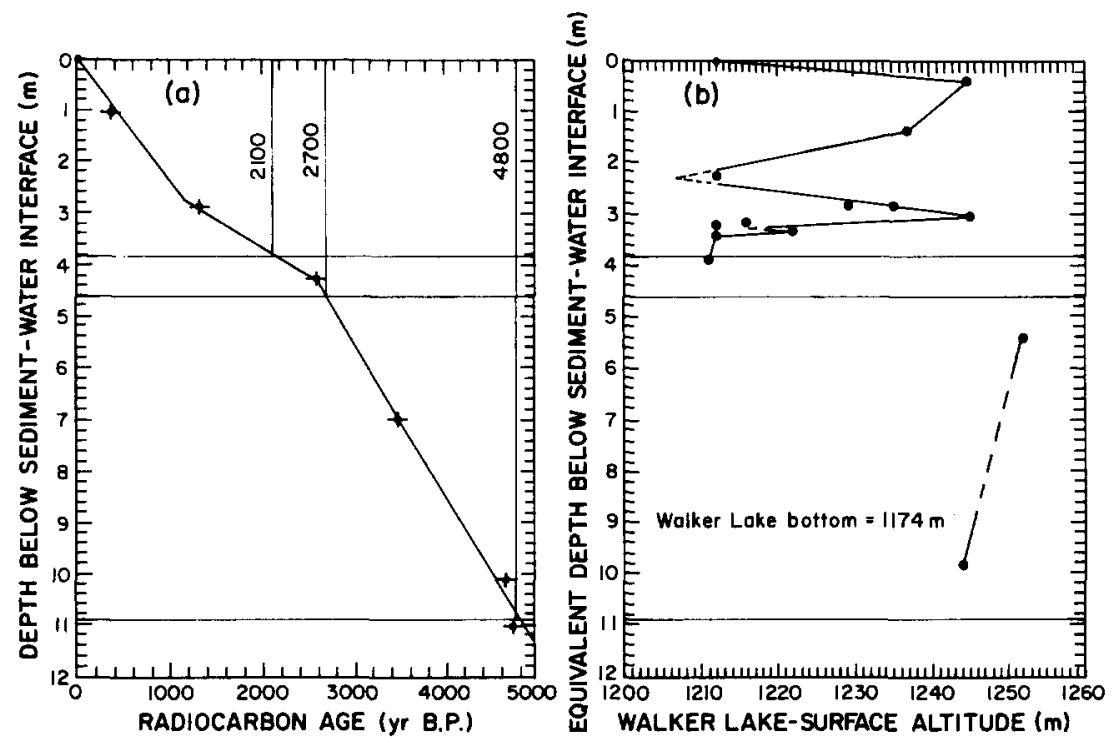

Fig.8. (a) Radiocarbon ages of the TOC fraction of sediments in WLC84-8 plotted as a function of core depth. (b) Altitude of tufas and one rooted tree stump in the Walker Lake subbasin plotted as a function of equivalent depth below the sediment-water interface at the WLC84-8 site.

\section{TABLE 1}

Radiocarbon ages and counting errors of surface samples in the Walker Lake subbasin. All samples have been corrected for measured $\delta^{13} \mathrm{C}$ except for LDGO samples for which it was assumed that $\delta^{13} \mathrm{C}=0$. The error introduced by this procedure is $<100 \mathrm{yr}$.

\begin{tabular}{lllll}
\hline $\begin{array}{l}\text { Sample } \\
\text { type }\end{array}$ & $\begin{array}{l}\text { Sample } \\
\text { number }\end{array}$ & $\begin{array}{l}\text { Laboratory } \\
\text { number }\end{array}$ & $\begin{array}{l}\text { Altitude } \\
(\mathrm{m})\end{array}$ & $\begin{array}{l}\text { Radiocarbon } \\
\text { age } \\
\text { (yr B.P.) }\end{array}$ \\
\hline Tufa & WL84-13 & USGS-4240174 & 1237 & $590 \pm 60$ \\
Tree & - & - & 1212 & $980 \pm 40$ \\
Tufa & WL7 & I-9362 & 1229 & $1205 \pm 75$ \\
Tufa & WL89-2 & LDGO-1743g & 1235 & $1210 \pm 40$ \\
Tufa & WL89-1 & LDGO-1743f & 1245 & $1290 \pm 60$ \\
Tufa & WL5 & I-9360 & 1216 & $1335 \pm 75$ \\
Tufa & WL86-1b & LDGO-1743e & 1212 & $1360 \pm 40$ \\
Tufa & WL6 & I-9361 & 1222 & $1720 \pm 80$ \\
Tufa & WL86-1a & LDGO-1743d & 1212 & $1800 \pm 40$ \\
Tufa & WL4 & I-9359 & 1211 & $2185 \pm 80$ \\
Tufa & WL10 & I-9365 & 1252 & $2970 \pm 85$ \\
Tufa & WL9 & I-9364 & 1244 & $4445 \pm 95$ \\
\hline
\end{tabular}

very low water levels and large areas of exposed lake sediment, which provided expanded habitat for Sarcobatus (Bradbury et al., 1989). The abundance of ditch grass (Ruppia) pollen in the upper greasewood zone indicates the presence of a shallow $(<1 \mathrm{~m})$ saline lake.
As noted in the preceding section, palynomorphs apparently can be used to delimit shallow-water intervals. However, palynological data are less informative on the nature of moderate- and deepwater phases. The higher abundances of the algae Botryococcus and Pediastrum in the interval between the two shallow-lake intervals may indicate more dilute water during the period since the last shallow-lake interval. However, changes in abundance of these taxa are poorly understood and factors other than salinity may control their abundance.

\section{Magnesium content of carbonates in WLC84-8}

The calcite content of WLC84-8 sediment is highly variable (Fig.11). Between $4.0-2.0 \mathrm{~m}$ and 12.0-7.0 m, samples average about $10 \%$ calcite; between $7.0-4.0 \mathrm{~m}$, samples average about $20 \%$ calcite with some samples containing as much as $35 \%$ calcite. Calcite was not detected in most samples above a depth of $2.0 \mathrm{~m}$; instead, small $(4 \mu \mathrm{m})$ crystals of monohydrocalcite are relatively abundant (Fig.11). Dolomite is present in small amounts in some samples between $10.0-8.0 \mathrm{~m}$ and $5.0-2.0 \mathrm{~m}$.

Systematic trends of increasing magnesium 


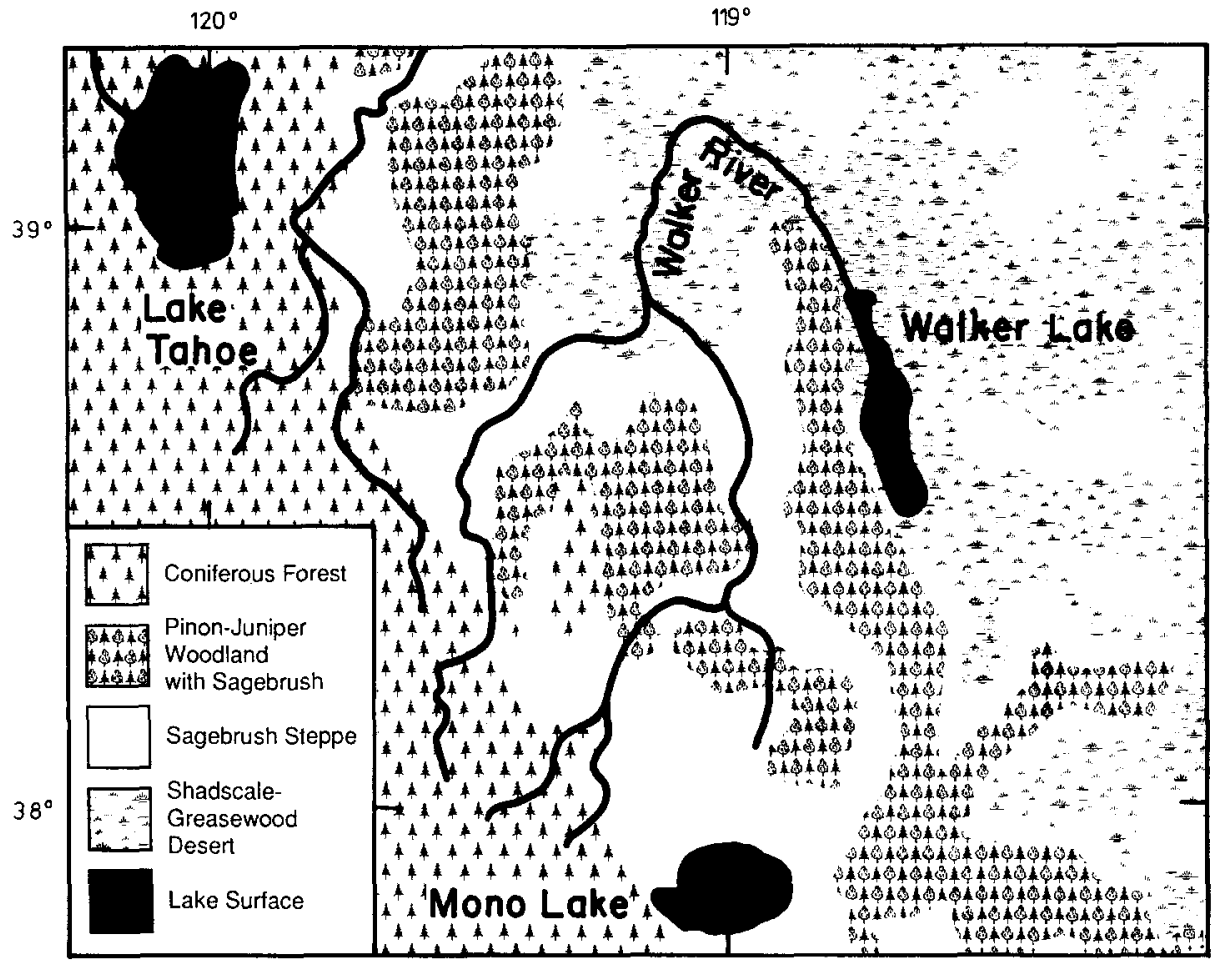

Fig.9. Modern areal distribution of major plant types in the Walker River subbasin (R. Thompson, pers. comm., 1990).

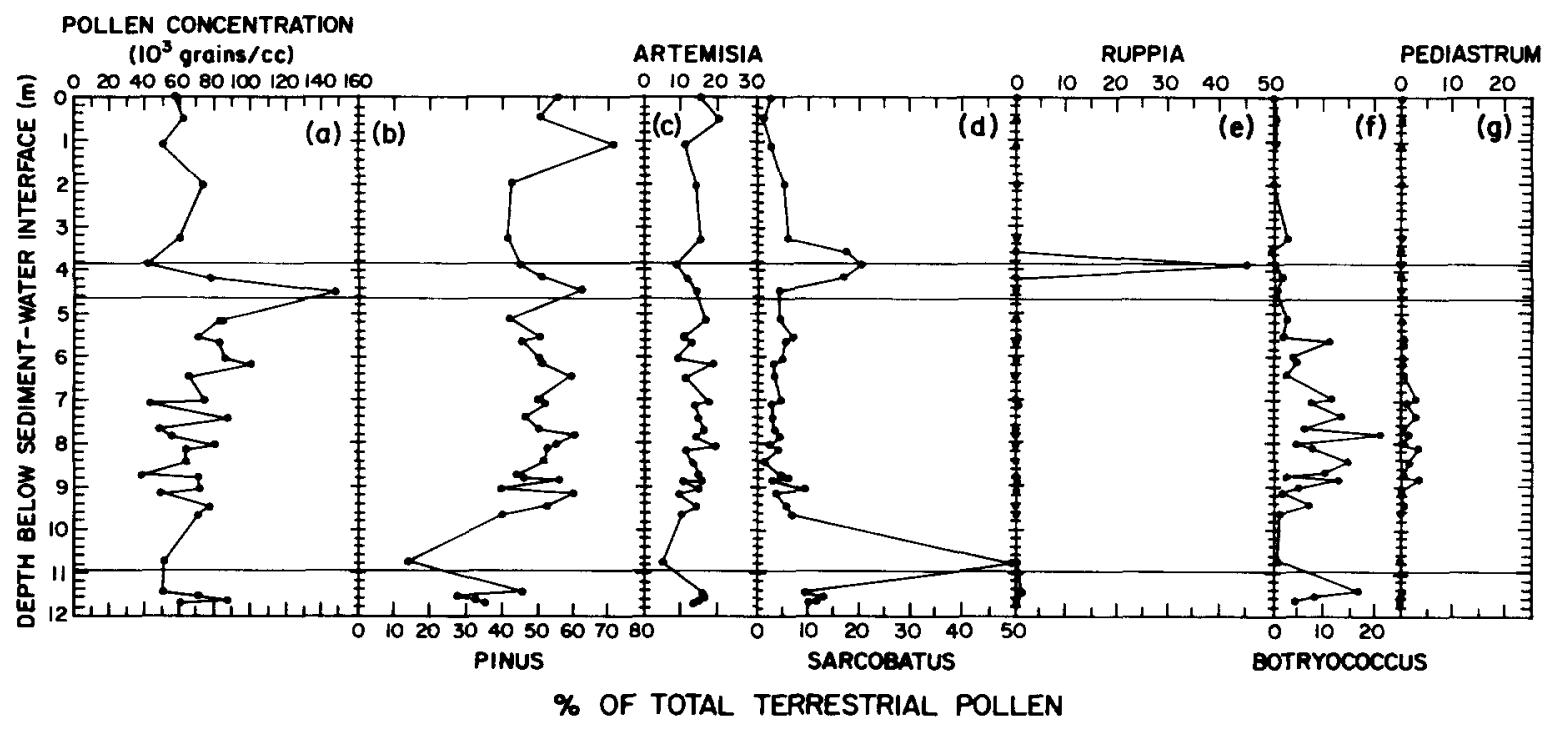

Fig. 10. Abundance of pollen and palynormorphs in WLC84-8 (adapted from Bradbury et al., 1989 and R. Thompson, pers. comm., 1990)

content occur between 10.9-7.4 $\mathrm{m}$ and $3.8-1.6 \mathrm{~m}$ (Fig.12a). To a first approximation, the systematic increase in magnesium content of calcite as a function of core depth can be considered to result from a fractionation process in which the magnesium/calcium ratio of lake water, as well as the magnesium/calcium ratio of calcite precipitated from lake water, increase as a function of the 


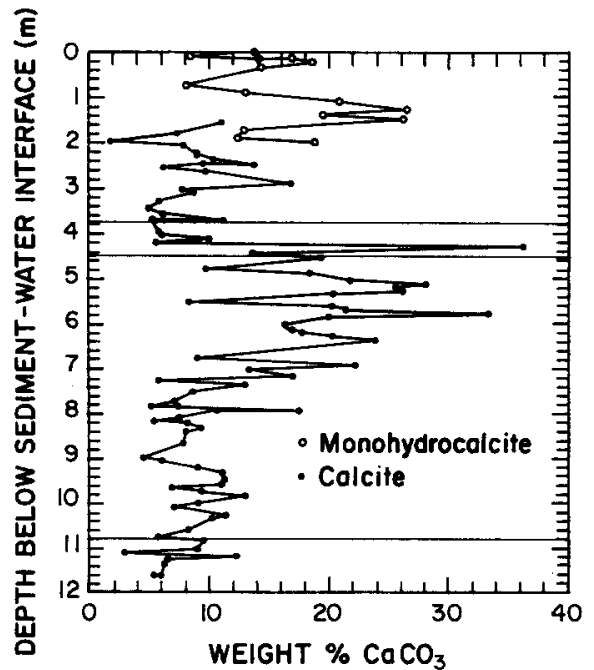

Fig.11. Amount of calcite and monohydrocalcite in WLC84-8.

amount of calcite precipitated. Because calcium is preferentially incorporated in the solid phase, the aqueous solution becomes enriched in magnesium during the chemical evolution of a closed-basin lake. For any instantaneous precipitation of calcite from a homogeneous solution, the ratio $\left(m_{\mathrm{Mg}} / m_{\mathrm{Ca}}\right)_{p}$ within the precipitate $(p)$ is related to the ratio $\left(m_{\mathrm{Mg}^{2}} / m_{\mathrm{Ca}^{2}}\right)_{l}$ in the aqueous solution (1) by the distribution coefficient $D_{\mathrm{Mg}}$ :

$\left(\frac{m_{\mathrm{Mg}}}{m_{\mathrm{Ca}}}\right)_{p}=D_{\mathrm{Mg}}\left(\frac{m_{\mathrm{Mg}^{2}+}}{m_{\mathrm{Ca}^{2}}}\right)_{l}$

where $D_{\mathrm{Mg}}$ is the heterogeneous-distribution coefficient of magnesium in calcite $\left(D_{\mathrm{Mg}}=0.012 \pm\right.$ 0.001 at $10^{\circ} \mathrm{C}$ and $0.019 \pm 0.001$ at $25^{\circ} \mathrm{C}$; Oomori et al., 1987).
The magnesium/calcium ratio in the calcite phase did not increase without limit during the chemical evolution of Walker Lake; i.e., after the $\left(m_{\mathrm{Mg}^{2}} / m_{\mathrm{Ca}^{2}}\right)_{l}$ ratio became sufficiently high, represented by a $\mathrm{MgCO}_{3}$ content of calcite of $\sim 11$ mole \%, monohydrocalcite became the principal carbonate precipitate (e.g., 2.0-0.0 m in WLC84-8; Fig.11) (see pp. 58-60 of Spencer, 1977 for a discussion of the formation of monohydrocalcite in recent sediments of Walker Lake). Thereafter, the magnesium content of lake water apparently was no longer constrained by precipitation of magnesium calcite.

Between 12.0-10.9 $\mathrm{m}$ and 7.4-3.8 $\mathrm{m}$, calcite averages about 1 mole $\% \mathrm{MgCO}_{3}$ (Fig.12a). Samples from the low-magnesium calcite $(<3 \%$ $\left.\mathrm{MgCO}_{3}\right)$ intervals contain large scalenohedral calcite crystals cemented in fine-grained calcite crusts (Fig.13) that are interpreted to indicate the product of recrystallization of metastable monohydrocalcite (Hull and Turnbull, 1973) in magnesium-depleted pore water.

Pore fluids in sediments from the central area of Walker Lake are depleted in magnesium (Table 2). At sediment depths $>1.5 \mathrm{~m}$, magnesium concentrations are $<3 \mathrm{mg} / \mathrm{L}$ (Benson and Spencer, 1983, table 12, WLC76-F and G). The loss of magensium from the pore water as a function of depth (time) has been attributed to uptake by clay minerals during their formation and alternation and to precipitation of low-magnesium calcite (Spencer, 1983). While the $\left(m_{\mathrm{Mg}^{2}} / m_{\mathrm{Ca}^{2}}\right)_{l}$ ratio of overlying lake water is $\sim 21$, at a depth of $1.45 \mathrm{~m}$ below the sediment-water interface, the $\left(m_{\mathrm{Mg}^{2}} / m_{\mathrm{Ca}^{2}+}\right)$, ratio of WLC76-G is 1.17 and at

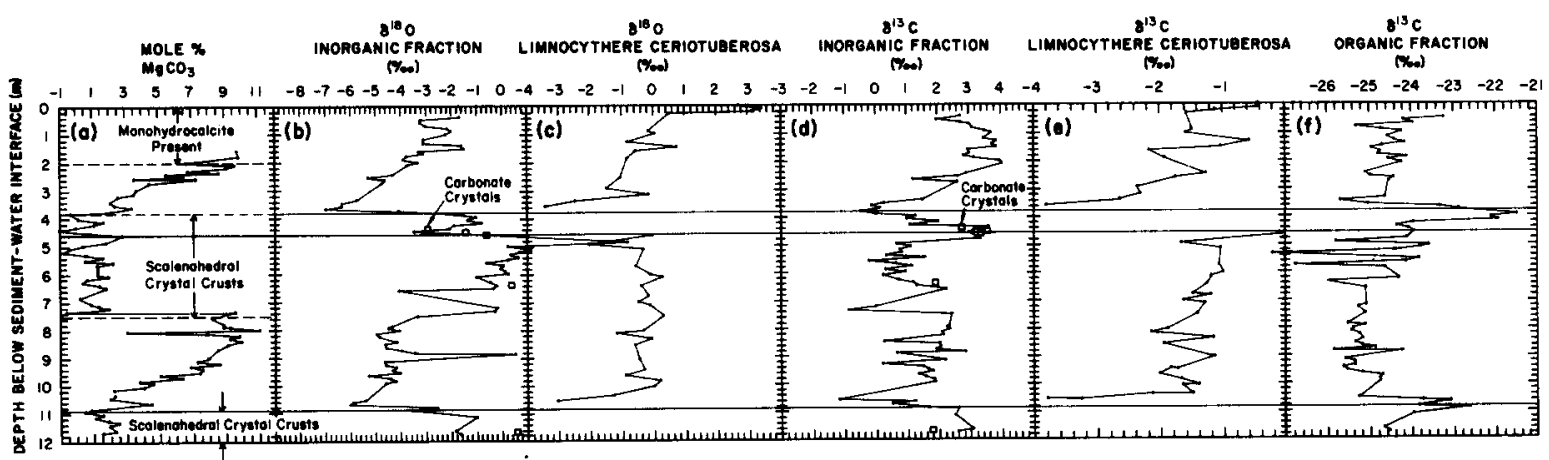

Fig.12. Mole \% $\mathrm{MgCO}_{3}$ and stable-isotope values in samples from WLC84-8. 


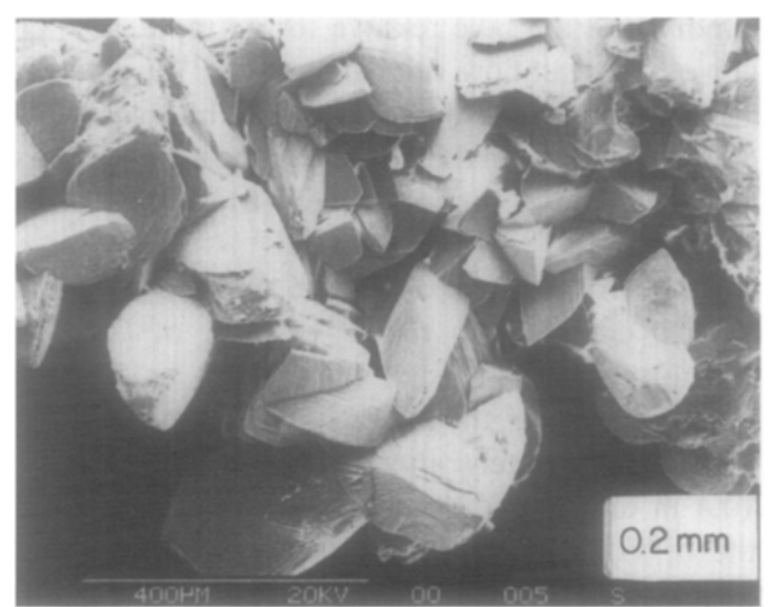

Fig.13. Scalenohedral calcite crystals cemented in fine-grained calcite crusts from $4.4 \mathrm{~m}$ in WLC84-8.

TABLE 2

Magnesium and $\delta^{18} \mathrm{O}$ values in pore fluids from selected cores from Walker Lake, Nevada

\begin{tabular}{llllll}
\hline Core & $\begin{array}{l}\text { Depth } \\
(\mathrm{m})\end{array}$ & $\begin{array}{l}\mathrm{Mg} \\
(\mathrm{mg} / \mathrm{L})\end{array}$ & Core & $\begin{array}{l}\text { Depth } \\
(\mathrm{m})\end{array}$ & $\begin{array}{l}\delta^{18} \mathrm{O} \\
(\% \mathrm{o})\end{array}$ \\
\hline WLC76-G & 0.45 & 40.0 & WLC84-1 & 2.0 & +0.0 \\
& 0.95 & 13.0 & & 8.2 & -2.2 \\
& 1.45 & 4.9 & WLC84-2 & 5.3 & -1.9 \\
& 1.95 & 1.6 & WLC84-4 & 4.0 & -1.3 \\
& 2.45 & 1.0 & & 12.1 & -2.3 \\
& 2.95 & 1.6 & & & \\
3.45 & 2.3 & & & \\
& 3.95 & 0.9 & & & \\
\hline
\end{tabular}

$4.50 \mathrm{~m}$ the ratio is 0.212 . Substitution of these values in Eq. 1 indicates that low-magnesium calcites (1.4 mole \% $\mathrm{MgCO}_{3}$ and 0.25 mole \% $\mathrm{MgCO}_{3}$ ) would result if monohydrocalcite were to recrystalize today to calcite at these depths.

Lake size (volume) is not easily inferred from the carbonate chemistry and mineralogy of WLC84-8; however, the data of Fig.12a indicate the following:

(1) Twice during the past $5300 \mathrm{yr}$, increasing magnesium/calcium ratios of Walker Lake water first led to the formation of magnesium calcites and then led to the formation of monohydrocalcite. At $\sim 3640$ yr B.P. and $\sim 840$ yr B.P. (Fig.12a, $7.4 \mathrm{~m}$ and $2.0 \mathrm{~m}$ ), precipitation of high-magnesium calcites $\left(\geqslant 10 \% \mathrm{MgCO}_{3}\right)$ ceased and precipitation of monohydrocalcite began.

(2) These two precipitation sequences can be modeled in terms of a fractionation process during which the magnesium/calcium ratio of lake water increased with the amount of carbonate precipitated.

(3) The occurrence of low-magnesium (2-3\% $\mathrm{MgCO}_{3}$ ) calcites immediately above the scalenahedral carbonate crusts probably indicates the reintroduction of dilute Walker River discharge to the lake basin.

The amount (wt. \%) of calcium carbonate is highest in sediment from above $2.0 \mathrm{~m}$ (monohydrocalcite interval) and between 7.0-4.4 m (recrystallized monohydrocalcite interval) in WLC84-8 (Fig.11). Age data (Fig.8a) do not indicate substantial differences in sediment accumulation rates in these intervals. Two models of carbonate sedimentation can be used to explain the carbonate accumulation data. In the first model, nucleation and precipitation of calcium carbonate occurs homogeneously within the epilimnion (carbonate whitings) when some arbitrary degree of supersaturation is achieved. In the homogeneous model, calcium carbonate accumulates in the sediment column at approximately equal rates over the entire lake-bottom surface and the amount of calcium available for precipitation is a function of discharge rate of the Walker River (Fig.5); i.e., the rate of carbonate accumulation at the WLC84-8 site increases when streamflow discharge increases causing the lake to rise. In the second model, precipitation of calcium carbonate preferentially occurs in the delta area at the north end of the lake where calcium-rich river water mixes with carbonate-rich lake water. In the deltaic model, the greatest accumulation rate of calcium carbonate occurs at the WLC84-8 site when it is near the delta when lake level is declining.

It remains impossible to unambiguously determine which calcium carbonate accumulation model best accounts for the calcium carbonate data depicted in Fig.11. Given the limited age data, change in the percentage of calcium carbonate may not indicate rates of carbonate accumulation but, instead, rates of dilution of the carbonate fraction by detrital silicates. However, if the lake- 
level envelope drawn around the tufa and rooted tree-stump ages is reasonably accurate (Fig. $8 \mathrm{~b}$ ), it appears that the homogeneous model of increased carbonate accumulation with lake-level rise is applicable to the Walker Lake system. In addition, during the two shallow-lake intervals, calcium carbonate percentages were small (Fig.11) even though the delta area was located near the core site, thus providing additional support for adoption of the homogeneous model of carbonate accumulation.

\section{$\delta^{18} O$ values of the total inorganic carbon fraction and L. ceriotuberosa in WLC84-8}

Definitions used in discussions of the stableisotope geochemistry of the Walker Lake system include the following

$R=\frac{\text { amount of rare isotope }}{\text { amount of abundant isotope }}$

where $\mathrm{R}={ }^{13} \mathrm{C} /{ }^{12} \mathrm{C}$ or ${ }^{18} \mathrm{O} /{ }^{16} \mathrm{O}$

$\alpha_{A}(B)=R_{B} / R_{A}$

where $\alpha_{a}(B)$ is the isotopic fractionation factor between components $A$ and $B$.

$\varepsilon_{A}(B)=\left[\alpha_{A}(B)-1\right] \times 10^{3} \%$

where $\varepsilon$ is the fractionation factor in \%o between components $A$ and $B$.

$\delta_{S}(A)=\left[\left(R_{A}-R_{S} / R_{S}\right] \times 10^{3} \%\right.$

where $\delta_{S}(A)$ is the isotope ratio of sample $A$ relative to standard $S$.

$\delta_{S}(B)-\delta_{S}(A) \approx \varepsilon_{A}(B)$

where $\delta_{S}(B)-\delta_{S}(A)$ is the difference in isotope ratio between components $A$ and $B$. Oxygen- and carbon-isotope fractionation factors used in this paper are taken from Friedman and O'Neil (1977).

$\delta^{18} \mathrm{O}$ values (relative to the PDB standard) in the TIC fraction, in hand-picked carbonate crystals, and in L. ceriotuberosa are shown in Fig.12b,c. Individual carbonate crystals and the TIC fraction of samples from shallow-lake intervals are isotopically enriched in ${ }^{18} \mathrm{O}$, indicating the importance of evaporative removal of ${ }^{18} \mathrm{O}$-depleted water vapor from the lake relative to the input of ${ }^{18} \mathrm{O}$ depleted streamflow discharge. No $\delta^{18} \mathrm{O}$ data for ostracodes exist for the shallow-lake intervals since ostracodes were unable to survive the high salinities that characterized these times (Bradbury et al., 1989).

Between depths of 11.1-10.6 and 4.0-3.6 m, a 5.0-6.0 depletion in the $\delta^{18} \mathrm{O}$ value of the TIC fraction occurs. This is interpreted to indicate initial refilling of the lake with ${ }^{18} \mathrm{O}$-depleted river water. Immediately above these intervals (10.6$10.4 \mathrm{~m}$ and $3.6-3.2 \mathrm{~m}$ ), a $2.0-4.0$ enrichment in the $\delta^{18} \mathrm{O}$ value of $L$. ceriotuberosa occurs. This enrichment is mirrored, to a lessor extent, by enrichment in the $\delta^{18} \mathrm{O}$ value of the TIC fraction between 10.6-10.4 and 3.6-3.2 m. The enrichment in the $\delta^{18} \mathrm{O}$ value of both forms of inorganic carbonate is interpreted to indicate the initial approach of the lake system to an isotopic steady state.

Between 10.4-5.2 m, little change occurs in the overall trend of $\delta^{18} \mathrm{O}$ in L. ceriotuberosa, indicating a balance between input of isotopically depleted river water and evaporative output of isotopically depleted water vapor. This implies a relative constancy of lake volume which is also indicated in the $\delta^{18} \mathrm{O}$ value of the TIC fraction, which averages about $\sim 4.5 \%$ between $10.0-7.8 \mathrm{~m}$. However, between $7.4-4.6 \mathrm{~m}$, the $\delta^{18} \mathrm{O}$ value of the TIC fraction is enriched, possibly indicating recrystallization in an isotopically enriched pore fluid (Table 2). The $\delta^{18} \mathrm{O}$ values of TIC samples from depths of 8.8 and $7.2 \mathrm{~m}$ also indicate levels of enrichment associated with shallow lakes or recrystallization beneath the sediment-water interface. Ostracode data are not available for these depths. There is some peak-to-peak correspondence in the two $\delta^{18} \mathrm{O}$ records between 11.0 and $7.0 \mathrm{~m}(10.8$, 9.5 and $8.2 \mathrm{~m}$, Fig. $12 \mathrm{~b}, \mathrm{c})$.

Between $3.6-2.0 \pm \mathrm{m}$, the $\delta^{18} \mathrm{O}$ values in both L. ceriotuberosa and the TIC fraction increase by $\sim 2.0$, indicating an overall decline in lake volume. ${ }^{18} \mathrm{O}$-depleted values for $L$. ceriotuberosa at 2.8 and $1.2 \mathrm{~m}$ and in the TIC fraction at $2.5,1.8,1.2$, and $0.6 \mathrm{~m}$ probably indicate increases in lake size due to sizeable inputs of isotopically depleted water. The $3.0 \%$ increase in the $\delta^{18} \mathrm{O}$ value of L. ceriotuberosa between $0.3-0.0 \mathrm{~m}$ is interpreted 
to have been caused by the $70 \%$ reduction in lake volume that occurred over the last $70 \mathrm{yr}$ (Fig.6).

Differences in the $\delta^{18} \mathrm{O}$ values of $L$. ceriotuberosa and the TIC fraction can be ascribed to several factors including:

\section{(1) Site of precipitation}

Precipitation of inorganic forms of calcium carbonate (calcite and aragonite) often occurs within the epilimnion of a lake when the lake becomes supersaturated with respect to one or more forms of calcium carbonate. These events, which are termed whitings, generally occur during the warmer months of the year (Kelts and Hsu, 1978). For example, whitings have been observed to occur in Pyramid Lake, Nevada, in August of 1973, 1978 , and 1980, and also may have occurred in September of 1957 (Galat and Jacobsen, 1985). The 1973, 1978, and 1980 whitings were all observed during an 8 -day period (July 30 -August 7) when maximum $0-10-\mathrm{m}$ deep mean-water temperature in the upper epilimnion ranged from 21.0 to $23.5^{\circ} \mathrm{C}$. The fractionation factor for $\delta^{18} \mathrm{O}$ between water and calcium carbonate is a function of temperature; a $2.5^{\circ} \mathrm{C}$ difference in the temperature of precipitation of calcite translates to a $0.55 \%$ difference in $\delta^{18} \mathrm{O}$.

Ostracodes are benthic organisms with calcite carapaces (two valves) that molt, generating sequentially larger valves up to nine times before reaching maturity (Chivas et al., 1986). The calcium incorporated in low-magnesium calcite valves is only acquired at the time of molting, which is completed within a few days (Turpen and Angell, 1971). A vital effect on ${ }^{18} \mathrm{O}$ fractionation between lake water and two different ostracode types was checked using four samples. L. ceriotuberosa was found to be depleted by $\sim 0.9 \pm 0.1 \%$ relative to Candona species no. 1 . Paired $L$. ceriotuberosa and TIC samples were not available for comparison.

The WLC84-8 site is located in the deepest part of Walker Lake where water temperature varies $<5^{\circ} \mathrm{C}$ annually (Benson and Spencer, 1983). If the ostracodes analyzed in this study were not transported from habitats situated above the base of the thermocline, the variability in the $\delta^{18} \mathrm{O}$ values of individual valves of $L$. ceriotuberosa due to moult- ing at different seasons of the year should not exceed $1.2 \%$. The presence of life proportions of juvenile and adult ostracode valves in samples from WLC84-8 supports the premise of a deep-water habitat (R. Forester, pers. comm. 1989). If the deep waters of Walker Lake were anoxic in Holocene summers as they are today (Benson and Spencer, 1983), ostracodes would have acquired their $\delta^{18} \mathrm{O}$ values during the cold season when the lake was oxygenated and isothermal and the change in temperature over the cold season minimal.

\section{(2) Chemistry of the precipitate}

The fractionation of ${ }^{18} \mathrm{O}$ between water and calcium carbonate also is a function of the magnesium content of the carbonate (Tarutani et al., 1969). The transition from $1-10$ mole $\% \mathrm{MgCO}_{3}$ between 10.9-7.4 and 3.8-1.6 $\mathrm{m}$ in WLC84-8 (Fig.12a) should have resulted in a 0.54 enrichment in ${ }^{18} \mathrm{O}$.

\section{(3) Sample depths and intervals}

Much of the fine-scale $(\leqslant 5 \mathrm{yr})$ variability in the $\delta^{18} \mathrm{O}$ values of the TIC fraction and $L$. ceriotuberosa is not comparable because the TIC and ostracode samples came from different depth intervals separated by $\sim 2.0-4.5 \mathrm{~cm}(6.5-20.0 \mathrm{yr})$.

\section{(4) Recrystallization of part of the TIC fraction}

As discussed previously (see p. 198), metastable forms of calcium carbonate, such as monohydrocalcite, may recrystallize to more stable forms. When this occurs, the carbonate acquires the isotopic composition of the fluid within which it recrystallizes. The enriched $\delta^{18} \mathrm{O}$ values of lowmagnesium calcites form between $7.6-4.6 \mathrm{~m}$ and from below $10.9 \mathrm{~m}$ in WLC84-8 indicate the effects of this process (Fig.12b).

As discussed previously (see p. 200-201), the high-frequency $(1.0 \pm \% 0)$ variability in $\delta^{18} \mathrm{O}$ that occurs throughout WLC84-8 may indicate past changes in water temperature or in lake volume. For example, a depletion in $\delta^{18} \mathrm{O}$ may result from either an increase in water temperature at the time of carbonate precipitation (see above) or from increased input of isotopically depleted river water (increased lake volume). Between September 1981 and September 1983, the volume of Walker Lake 
increased by $\sim 0.83 \mathrm{~km}^{3}$ or $28 \%$ of its September 1981 value (Fig.14). The $\delta^{18} \mathrm{O}$ value of lake water correspondingly decreased $3.6 \%$ from a value of +1.9 to $-1.7 \%$ (J. White, pers. comm., 1989; table 11 in Benson, 1988). Between 1920 and 1981, the volume of Walker Lake decreased by $7.4 \mathrm{~km}^{3}$, or $70 \%$ of its 1920 volume. During this time, the $\delta^{18} \mathrm{O}$ value of $L$. ceriotuberosa increased by $3.0 \%$ (0.3-0.1 m interval of Fig. 12c). This idicates that change in the $\delta^{18} \mathrm{O}$ value of water in a closedbasin lake is not a simple function of amount of change in lake volume but is dependent on the relative rates of input and output of water.

The $\delta^{18} \mathrm{O}$ value of the TIC fraction averages $\sim 4 \%$ more depleted than the $\delta^{18} \mathrm{O}$ value of L. ceriotuberosa (Fig.12b,c). This is exactly the difference in $\delta^{18} \mathrm{O}$ that would result from precipitation of most of the TIC fraction as whitings at $\sim 22.0^{\circ} \mathrm{C}$ in late August or early September and from molting of L. ceriotuberosa at $\sim 5.0^{\circ} \mathrm{C}$ in bottom sediments. This indicates that most of the second-order Holocene variability in $\delta^{18} \mathrm{O}$ was due to change in lake volume and not to change in lake temperature. Differences of $<4 \%$ in the $\delta^{18} \mathrm{O}$ values of the TIC fraction and L. ceriotuberosa from the same depth in core can, in part, be attributed to the fact that $L$. ceriotuberosa makes up a variable part of the TIC fraction.

\section{$\delta^{13} \mathrm{C}$ values of the total inorganic carbonate} fraction and L. ceriotuberosa in WLC84-8

$\delta^{13} \mathrm{C}$ values in the TIC fraction, in hand-picked carbonate crystals, and in L. ceriotuberosa are

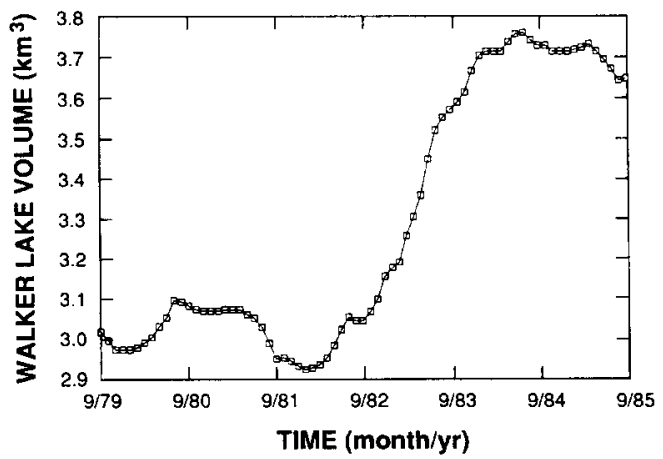

Fig.14. Change in the volume of Walker Lake from September 1979 through September 1985. shown in Fig.12d and e. Individual carbonate crystals and the TIC fraction are isotopically enriched in all samples from the lower shallowlake interval and in the lower one-half of the upper shallow-lake interval. There is little or no peakto-peak correspondence in the $\delta^{13} \mathrm{C}$ values of the TIC fraction and L. ceriotuberosa. However, there is a significant degree of correspondence in trends and peak-to-peak variabilities in the $\delta^{13} \mathrm{C}$ and $\delta^{18} \mathrm{O}$ values of $L$. ceriotuberosa and in the $\delta^{13} \mathrm{C}$ and $\delta^{18} \mathrm{O}$ values of the TIC fraction (compare Fig.12c,e and Fig.12b,d). Note especially the covariance of the $\delta^{13} \mathrm{C}$ and $\delta^{18} \mathrm{O}$ values of L. ceriotuberosa in the top $3 \mathrm{~m}$ of WLC84-8.

The $\delta^{13} \mathrm{C}$ value of preindustrial atmospheric $\mathrm{CO}_{2}$ averaged $\sim-6.5 \%$. When $\mathrm{CO}_{2}$ is incorporated into precipitation as $\mathrm{HCO}_{3}^{-}$, fractionation of the carbon isotopes occurs. For example, if the temperature of condensation is $5^{\circ} \mathrm{C}$, the fractionation factor for $\mathrm{CO}_{2}(\mathrm{~g})-\mathrm{CO}_{2}(\mathrm{aq})$ is -1.15 and the $\delta^{13} \mathrm{C}$ value of $\mathrm{CO}_{2}(\mathrm{aq})$ in precipitation becomes $-8.2 \%$.

Precipitation in the Sierra Nevada, which border the Walker Lake subbasin, consists of a dilute, acidic ( $\mathrm{pH}=5.6)$, aqueous solution that contains small amounts of dissolved inorganic carbon (DIC) ( $\leqslant 1 \mathrm{mg} / \mathrm{L}$ alkalinity reported as $\mathrm{HCO}_{3}^{-}$, table 7 in Benson and Spencer, 1983). The concentration of $\mathrm{HCO}_{3}^{-}$, at the mouth of the Walker River is $\geqslant 100 \mathrm{mg} / \mathrm{L}$ (Benson and Spencer, 1983). Therefore, the amount of DIC and the $\delta^{13} \mathrm{C}$ value of water that reaches the Walker River mainly is a function of chemical reactions that occur between infiltrating precipitation and organic and inorganic materials found in the soil zone.

Vegetation along the Walker River drainage has $\delta^{13} \mathrm{C}$ values that indicate the type of photosynthetic pathway used in the assimilation of $\mathrm{CO}_{2}$. The Calvin (C3) group of plants have $\delta^{13} \mathrm{C}$ values of about $-25 \%$ and the Hatch-Slack (C4) group have $\delta^{13} \mathrm{C}$ values of about $-13 \%$ (Table 3 ). The $\delta^{13} \mathrm{C}$ of $\mathrm{CO}_{2}(\mathrm{~g})$ in the soil atmosphere is enriched $\sim 4.4 \%$ relative to the $\delta^{13} \mathrm{C}$ of decaying plants found in the soil (Cerling, 1984; Quade et al., 1989). Therefore, decaying $C 3$ vegetation. will give rise to soil water with $\mathrm{HCO}_{3}^{-} \delta^{13} \mathrm{C}$ values of about $-12 \%$; and $\mathrm{C} 4$ vegetation will give rise to soil water with $\mathrm{HOC}_{3}^{-} \delta^{13} \mathrm{C}$ values of $\sim 0 \%$. 
TABLE 3

$\delta^{13} \mathrm{C}$ values of vegetation from the Walker Lake subbasin

Vegetation type $\quad \delta^{13} \mathrm{C}$

$(\%)$

\begin{tabular}{lr} 
Deciduous trees (C3) & \\
willow (Salix ssp) & -26.7 \\
aspen (Populus tremuloides) & -25.8 \\
cottonwood (Populus ssp) & -25.0 \\
Coniferous trees (C3) & \\
pinon (Pinus monophylla) & -24.8 \\
juniper (Juniperus ssp) & -22.5 \\
Shrubs (C3) & \\
big sage (Artemisia tridenta) & -26.4 \\
rabbitbrush (Chrysothamnus ssp) & -25.2 \\
greasewood (Sarcobatus vermiculatus) & -23.5 \\
mormon tea (Ephedra ssp) & -23.4 \\
mountain mahogany (Cercocarpus ssp) & -23.1 \\
Shrubs (C4) & \\
salt grass (Distichlus spicata) & -14.1 \\
green molly (Kochin scoparia) & -13.3 \\
shadscale (Atriplex confertifolia) & -12.9 \\
tumbleweed (Salsola kali) & -12.5 \\
Aquatic plants & \\
mixed plankton & \\
Nodularia & \\
Nodularia & -28.8 (May, 1986) \\
\hline
\end{tabular}

The dissolution of soil-zone carbonates can enrich the $\delta^{13} \mathrm{C}$ value of dissolved $\mathrm{HCO}_{3}^{-}$ (Broecker and Walton, 1959). Ancient marine carbonates have $\delta^{13} \mathrm{C}$ values of $\sim 0 \%$ (Veizer and Hoefs, 1976); and the $\delta^{13} \mathrm{C}$ of secondary carbonates in semiarid regions often ranges from +5 to -9 (Quade et al., 1989). However, if complete isotopic equilibrium occurs between $\mathrm{CO}_{2}(\mathrm{~g})$ in the soil atmosphere and DIC species in the soil water, the $\delta^{13} \mathrm{C}$ value of soil water is not influenced by the $\delta^{13} \mathrm{C}$ value of dissolving carbonates but is determined by the $\delta^{13} \mathrm{C}$ value and temperature of the soil gas (Cerling, 1984; Salomons and Mook, 1986; Quade et al., 1989).

The $\delta^{13} \mathrm{C}$ value of DIC at the mouth of the Walker River was -16\% in 1979 (Peng and Broecker, 1980). Equilibrium distribution-of-species calculations indicate that $\mathrm{HCO}_{3}^{-}$comprises $>99 \%$ of DIC in 92 samples taken from the Walker River in June of 1985 (Benson and Spencer, 1983). Therefore, the $-16 \% \delta^{13} \mathrm{C}$ value of Walker
River water indicates that soil gas formed from decay of C3 plant material has strongly influenced the $\delta^{13} \mathrm{C}$ value of Walker River water.

The $\delta^{13} \mathrm{C}$ value in Walker Lake was $+3.0 \%$ in September, 1976, and in May, 1978 (Peng and Broecker, 1980) and $+2.5 \%$ in August, 1983 (R. Wanninkhof, pers. comm., 1989). Equilibrium distribution-of-species calculations indicate that Walker Lake DIC consisted of $\sim 20 \% \mathrm{CO}_{3}^{2-}$ and $\sim 80 \% \mathrm{HCO}_{3}^{-}$in 1975 and 1976 (Benson and Spencer, 1983). The $\delta^{13} \mathrm{C}$ value of Walker Lake DIC $\left(\mathrm{HCO}_{3}^{-}+\mathrm{CO}_{3}^{2-}\right)$ in equilibrium with the atmosphere is about +3.1 at $5^{\circ} \mathrm{C}$ and about $+1.4 \%$ at $20^{\circ} \mathrm{C}$. This indicates that equilibrium with atmospheric $\mathrm{CO}_{2}(\mathrm{~g})$ and its $\delta^{13} \mathrm{C}$ value is approached in Walker Lake today. The amount of DIC stored in Walker Lake is so large (Table 4) that the man-annual input of $\delta^{13} \mathrm{C}$ depletes the $\delta^{13} \mathrm{C}$ value of the lake by only about $0.04 \% \mathrm{~d}$.

At any point in the chemical evolution of a closed-basin lake, the $\delta^{13} \mathrm{C}$ value of the DIC is a function of several processes that control the transfer of carbon between the lake and its surrounding environment.

\section{(1) Input of carbon via streamflow discharge}

As discussed above, the $\delta^{13} \mathrm{C}$ value of the DIC in the Walker River (about $-16 \%$ ) is presently controlled by the decay of $\mathrm{C} 3$ plant material. There are no data that indicate the $\mathrm{C} 3 / \mathrm{C} 4$ plant ratio in the Walker River subbasin varied during the past $5000 \mathrm{yr}$. Therefore, it is assumed that the $\delta^{13} \mathrm{C}$ value of the DIC in the Walker River has remained at a value of $-16 \%$ during the past $5000 \mathrm{yr}$. The total amount of carbon annually reaching Walker Lake by discharge from the Walker River totals $4.01 \times 10^{8}$ moles (Table 4).

\section{(2) Storage of carbon beneath the sediment- water interface}

Nearly all the organic and inorganic forms of carbon stored in the sediments of Walker Lake acquire their carbon from DIC species. The amount of inorganic carbon annually precipitated in Walker Lake is limited by the amount of calcium supplied by the Walker River $\left(9.75 \times 10^{7}\right.$ moles/ yr, Table 4). 


\section{TABLE 4}

Miscellaneous physical and chemical data for the Walker Lake subbasin; $\mathbf{M}=$ moles

Walker Lake bathymetry (1975-1976)

Lake-surface elevation $1209 \mathrm{~m}$

Lake-surface area $1.50 \times 10^{8} \mathrm{~m}^{2}$

Lake volume $3.55 \times 10^{12} \mathrm{~L}$

Walker River mass flux (1940-1987)

\begin{tabular}{|c|c|c|}
\hline $\begin{array}{l}\text { Chemical } \\
\text { species }\end{array}$ & $\begin{array}{l}\text { Number of } \\
\text { observations }\end{array}$ & $\begin{array}{l}\text { Mole flux } \\
(\mathrm{M} / \mathrm{yr})\end{array}$ \\
\hline DOC & 14 & $6.13 \times 10^{7}$ \\
\hline POC & 14 & $1.30 \times 10^{7}$ \\
\hline DIC & 166 & $3.27 \times 10^{8}$ \\
\hline Calcium & 166 & $9.75 \times 10^{7}$ \\
\hline Magnesium & 166 & $3.69 \times 10^{7}$ \\
\hline Sodium & 166 & $2.09 \times 10^{8}$ \\
\hline Potassium & 166 & $1.43 \times 10^{7}$ \\
\hline Alk (as $\mathrm{HCO}_{3}$ ) & 166 & $3.27 \times 10^{8}$ \\
\hline Chloride & 166 & $4.30 \times 10^{7}$ \\
\hline Sulfate & 166 & $5.58 \times 10^{7}$ \\
\hline Silica (as $\mathrm{SiO}_{2}$ ) & 166 & $4.50 \times 10^{7}$ \\
\hline \multicolumn{3}{|c|}{ Mean field $\mathrm{pH}=8.2$ for 101 observations } \\
\hline \multicolumn{3}{|c|}{$\begin{array}{l}\text { Walker River reconstructured mean annual streamflow } d \\
\text { charge }=0.38 \mathrm{~km}^{3} / \mathrm{yr}\end{array}$} \\
\hline \multicolumn{3}{|c|}{ Mass of solids dissolved in Walker Lake (1975-1976) } \\
\hline $\begin{array}{l}\text { Chemical } \\
\text { species }\end{array}$ & $\begin{array}{l}\text { Concentration } \\
(\mathrm{M} / \mathrm{L})\end{array}$ & $\begin{array}{l}\text { Mass } \\
(\mathrm{M})\end{array}$ \\
\hline DIC & 0.0467 & $1.66 \times 10^{11}$ \\
\hline Calcium & 0.00027 & $9.6 \times 10^{8}$ \\
\hline Magnesium & 0.00559 & $1.98 \times 10^{10}$ \\
\hline Sodium & 0.1357 & $4.82 \times 10^{11}$ \\
\hline Potassium & 0.00419 & $1.49 \times 10^{10}$ \\
\hline Alk (as $\mathrm{HCO}_{3}$ ) & 0.0467 & $1.66 \times 10^{11}$ \\
\hline Chloride & 0.0637 & $2.26 \times 10^{11}$ \\
\hline Sulfate & 0.0215 & $7.63 \times 10^{10}$ \\
\hline Silica (as $\mathrm{SiO}_{2}$ ) & 0.000012 & $4.3 \times 10^{7}$ \\
\hline \multicolumn{3}{|c|}{ Mean field $\mathrm{pH}=9.4$ for 35 observations } \\
\hline
\end{tabular}

Sediments in Walker Lake below the zone where organic carbon is actively recycled $(0.2 \mathrm{~m})$ and above the top of the first volcanic ash (age $=$ $750 \mathrm{yr}$ B.P. in WLC $84-8$ ) average $\sim 2.5 \%$ carbon by weight (Table 5 ). The mean sedimentation rate in Walker Lake is $\sim 1.5 \mathrm{~mm} / \mathrm{yr}$ and sediment porosity averages $\sim 80 \%$ (Benson and Spencer, 1983). If a mean grain density of $2.5 \mathrm{~g} / \mathrm{cm}^{3}$ is assumed for Walker Lake sediments, an accumulation rate of $\sim 5 \times 10^{8}$ moles $/ y r$ of organic carbon is indicated.
Most of the organic carbon in the standing crop of Walker Lake is contained in Nodularia spumigena, a filamentous, nitrogen-fixing cyanobacterium (blue-green alga) (Koch et al., 1979). The $\delta^{13} \mathrm{C}$ value of Walker Lake water was $2.5 \%$ in August, 1983 (R. Wanninkhof, pers. comm. 1989) and the $\delta^{13} \mathrm{C}$ value of Nodularia in Walker Lake in 1984 and 1985 was -24.0 and -18.6 (Table 3 ), indicating a mean- $\delta^{13} \mathrm{C}$ fractionation factor of about $-24.0 \%$. The mean $\delta^{13} \mathrm{C}$ value of two mixed plankton samples taken in 1986 from Walker Lake was $-28.8 \%$ (Table 3 ), indicating a $\delta^{13} \mathrm{C}$ fractionation factor of about $-31.0 \%$ for mixed plankton.

The $\delta^{13} \mathrm{C}$ value of Walker Lake sediments averages about $-25 \%$ (Fig.12f). If a $\delta^{13} \mathrm{C}$ fractionation factor for TOC stored in the sediments of Walker Lake is assumed to be $-25 \%$ (a value near that of Nodularia), and if loss of organic carbon to storage is assumed to occur instantaneously, the $\delta^{13} \mathrm{C}$ of present-day Walker Lake DIC is depleted by only $0.06 \%$ during growth and storage of TOC in the form of Nodularia. Only when Walker Lake contained much less DIC did the seasonal storage of organic carbon have a substantial effect on its $\delta^{13} \mathrm{C}$. For example, when Walker Lake contained only $10 \%$ of its present amount of DIC, loss of $5 \times 10^{8}$ moles of TOC to storage would have resulted in a depletion of $0.75 \%$ in the $\delta^{13} \mathrm{C}$ value of lake water. Depletion in the $\delta^{13} \mathrm{C}$ value of lake water would be even less if storage of TOC were spread over some finite length of time because continual exchange of carbon across the air-water interface would tend to counteract the depletion (see p. 205).

Precipitation of inorganic carbon has an even smaller effect on the $\delta^{13} \mathrm{C}$ value of Walker Lake DIC. Today, instantaneous precipitation of $9.75 \times 10^{7}$ moles of inorganic carbon would enrich the $\delta^{13} \mathrm{C}$ value of Walker Lake DIC by only $0.0004 \%$. Therefore, it is concluded that storage of TOC and TIC has had a minimal effect on the $\delta^{13} \mathrm{C}$ value of Walker Lake DIC.

\section{(3) Temporary loss of carbon through increased productivity}

Although the causes of Nodularia blooms are complex, the size of a bloom probably is limited by the amount of available phosphorus (Galat and 
TABLE 5

Organic carbon contents (wt. \%) in WLC75-B, C, and D

\begin{tabular}{|c|c|c|c|c|c|c|c|c|}
\hline Core & $\begin{array}{l}\text { Depth } \\
\text { (m) }\end{array}$ & $\begin{array}{l}\text { TOC } \\
\text { (wt. \%) }\end{array}$ & Core & $\begin{array}{l}\text { Depth } \\
\text { (m) }\end{array}$ & $\begin{array}{l}\text { TOC } \\
\text { (wt. \%) }\end{array}$ & Core & $\begin{array}{l}\text { Depth } \\
\text { (m) }\end{array}$ & $\begin{array}{l}\text { TOC } \\
\text { (wt. \%) }\end{array}$ \\
\hline \multirow[t]{13}{*}{ 75-B } & 0.20 & 3.97 & \multirow[t]{14}{*}{$75-\mathrm{C}$} & 0.20 & 1.94 & \multirow[t]{14}{*}{ 75-D } & 0.20 & 1.56 \\
\hline & 0.30 & 1.53 & & 0.30 & 2.29 & & 0.30 & 2.43 \\
\hline & 0.40 & 1.88 & & 0.40 & 2.46 & & 0.40 & 3.35 \\
\hline & 0.50 & 4.33 & & 0.50 & 2.68 & & 0.50 & 4.58 \\
\hline & 0.60 & 2.29 & & 0.60 & 2.71 & & 0.60 & 1.98 \\
\hline & 0.70 & 2.39 & & 0.70 & 2.35 & & 0.70 & 2.80 \\
\hline & 0.80 & 2.26 & & 0.80 & 2.78 & & 0.80 & 1.65 \\
\hline & 0.90 & 2.97 & & 0.90 & 2.49 & & 0.90 & 3.38 \\
\hline & 1.00 & 3.63 & & 1.00 & 1.68 & & 1.00 & 1.29 \\
\hline & 1.10 & 2.18 & & 1.10 & 1.81 & & & \\
\hline & 1.20 & 2.92 & & & & & & \\
\hline & 1.30 & 1.84 & & & & & & \\
\hline & 1.40 & 1.78 & & & & & & \\
\hline$n=32$ & $\chi=2.51$ & $\sigma=0.82$ & & & & & & \\
\hline
\end{tabular}

Verdin, 1988). The maximum daily photosynthetic rate observed in Pyramid Lake, Nevada, during a Nodularia bloom was $250 \mathrm{mg} \mathrm{C} / \mathrm{m}^{3}$ (Galat, 1986). These blooms usually last for only a few days (Galat and Verdin, 1988). If a bloom of this magnitude continued for 30 days in Walker Lake, 0.62 millimoles $\mathrm{C} / \mathrm{L}$ would be transferred to the standing crop of Nodularia. This represents a conversion of only $0.087 \%$ of the DIC in Walker Lake and would not affect the $\delta^{13} \mathrm{C}$ value of the DIC reservoir.

\section{(4) Exchange of carbon across the air-water} interface

Peng and Broecker (1980) have shown that the mean $\mathrm{CO}_{2}(\mathrm{~g})$ invasion rate for Walker Lake is $\sim 15$ moles $\mathrm{m}^{-2} \mathrm{yr}^{-1}$. The 1975-1976 surface area of Walker Lake was $1.50 \times 10^{8} \mathrm{~m}^{2}$. This indicates that $2.25 \times 10^{9}$ moles of atmospheric $\mathrm{CO}_{2}$ entered Walker Lake in 1975 and 1976, replacing an equivalent amount of DIC. The equation describing equilibrium of DIC with atmospheric $\mathrm{CO}_{2}$ can be written

$M=M_{\mathrm{o}} \exp \left(-t / t_{\mathrm{o}}\right)$

where $M$ is the concentration of carbon at time $t$, $M_{\mathrm{o}}$ is the original concentration, and $t_{\mathrm{o}}$ is the decay time constant.
$M=M_{\mathrm{o}} \exp (-1)=0.37 M_{\mathrm{o}}$ when $t=t_{\mathrm{o}}$

where the e-folding time $\left(t=t_{\mathrm{o}}\right)$ is related to the carbon invasion rate $(I R)$, surface area $(A)$, and original concentration of DIC $\left(M_{\mathrm{o}}\right)$ in Walker Lake by

$t_{\mathrm{o}}=M_{\mathrm{o}} / I R \times A=74 \mathrm{yr}$

Therefore, in $74 \mathrm{yr}, 63 \%$ of equilibrium is achieved between Walker Lake DIC and atmospheric $\mathrm{CO}_{2}$. Since Walker Lake contains $1.66 \times 10^{11} \mathrm{M}$ of DIC and $t_{\mathrm{o}}=74 \mathrm{yr}$, it would take $\sim 450 \mathrm{yr}$ for the DIC in Walker Lake to reach $99 \%$ of equilibrium with respect to atmospheric $\mathrm{CO}_{2}$.

In. Walker Lake, the DIC reservoir is essentially infinite with respect to storage of TIC and TOC and change in productivity. Therefore, the hypothesis is offered that depletions in $\delta^{13} \mathrm{C}$ of WLC84-8 inorganic carbonates are due to extreme discharge events (floods). In this hypothesis, the mass of isotopically depleted water entering the lake is so large that isotopic exchange across the air-water interface cannot rapidly reset the $\delta^{13} \mathrm{C}$ value of the lake to values in equilibrium with the atmosphere. For example, if $10 \times$ the mean-annual river-borne mass of carbon (Table IV) were instantaneously put into present-day Walker Lake, the $\delta^{13} \mathrm{C}$ value of DIC in the lake would decrease from $+2.5 \%$ to $+2.1 \%$. 
The flood hypothesis is consistent with the previous conclusion that most of the second-order depletions in $\delta^{18} \mathrm{O}$ were due to increases in the volume of Walker Lake resulting from increased discharge of the Walker River (see p. 200). The sampling interval in WLC84-8 is not small enough to determine whether one or more successive flood events were responsible for observed depletions in $\delta^{13} \mathrm{C}$. However, since reconstructed historical (1871-1986) discharges of the Walker Lake have never exceeded $1.0 \mathrm{~km}^{3} / \mathrm{yr}(2.6 \times$ the mean-historical value) (Benson and Paillet, 1989), it is suggested that $\delta^{13} \mathrm{C}$ depletions in excess of $0.15 \%$ probably resulted from successive years of above-normal streamflow discharge. It follows that the overall correspondence in trends and peak-to-peak variability in the $\delta^{13} \mathrm{C}$ and $\delta^{18} \mathrm{O}$ values of L. ceriotuberosa and in the $\delta^{13} \mathrm{C}$ and $\delta^{18} \mathrm{O}$ values of the TIC fraction stem from the same cause variability in the amount of steamflow discharge.

The present-day $\delta^{13} \mathrm{C}$ value of bicarbonate in Walker Lake is about $+2.6 \%$. Therefore, the $\delta^{13} \mathrm{C}$ value of TIC (whitings) precipitated at $\sim 22^{\circ} \mathrm{C}$ should be about $+3.3 \%$ and the $\delta^{13} \mathrm{C}$ value of L. ceriotuberosa formed at about $5^{\circ} \mathrm{C}$ should be about +2.5 . The $\delta^{13} \mathrm{C}$ value of the TIC fraction from the upper part of WLC84-8 is near the expected value. However, the $\delta^{13} \mathrm{C}$ value of $L$. ceriotuberosa from the upper part of WLC84-8 exceeds its theoretical value by $>1 \%$. In addition, the difference in the $\delta^{13} \mathrm{C}$ value of the TIC fraction and the $\delta^{13} \mathrm{C}$ value of $L$. ceriotuberosa is substantially greater than the $0.8 \%$ value resulting from a $17^{\circ} \mathrm{C}$ difference in temperature of formation (Fig.12d, e). This indicates that $L$. ceriotuberosa exerts a strong influence (vital effect) over its own $\delta^{13} \mathrm{C}$ value.

\section{$\delta^{13} C$ value of the total organic carbon fraction in WLC84-8}

The $\delta^{13} \mathrm{C}$ value of the TOC fraction averages $\sim-25 \%$ during the relatively deep-lake intervals. During the upper part of shallow-lake intervals, the TOC is more enriched in ${ }^{13} \mathrm{C}$, achieving values of -21.5 to $-22.5 \%$. The enriched values are attributed to growth of plankton and Nodularia in a ${ }^{13} \mathrm{C}$-depleted water together with increased input of $\mathrm{C} 4$ vegetation from the lake periphery (Table 3 ,
Fig.9). The $\delta^{13} \mathrm{C}$ value of the DIC fraction was $\sim+2$ to $+3 \%$ during the upper part of the shallow-lake intervals. Using the fractionation factors listed in Friedman and O'Neil (1977) and a $\delta^{13} \mathrm{C}$ fractionation factor of $-25 \%$ for Nodularia, a $\delta^{13} \mathrm{C}$ range of -22.5 to $-23.5 \%$ for TOC derived from Nodularia debris is calculated. This range of values is consistent with measured $\delta^{13} \mathrm{C}$ values for TOC from the upper part of the shallowlake intervals.

There is a substantial amount of peak-to-peak correspondence in the $\delta^{13} \mathrm{C}$ record for TOC and the $\delta^{13} \mathrm{C}$ and $\delta^{18} \mathrm{O}$ records for TIC in WC84-8 (Fig.12b, d, f). The correspondence in the two $\delta^{13} \mathrm{C}$ records is attributed to the fact that both TOC and TIC share the same carbon reservoir Walker Lake DIC. The correspondence between the $\delta^{13} \mathrm{C}$ value of TOC and the $\delta^{18} \mathrm{O}$ value of TIC indicates that the TOC and TIC formed in a lake that sometimes received large amounts of isotopically depleted water (floods).

The magnitude of long-term trends in the $\delta^{13} \mathrm{C}$ value of TOC do not match long-term trends in the $\delta^{13} \mathrm{C}$ value of TIC. For example, between $3.8-2.0 \mathrm{~m}$ in WLC84-8, the $\delta^{13} \mathrm{C}$ value of TIC is enriched by $4.2 \%$, while the $\delta^{13} \mathrm{C}$ value of TOC is only enriched by about $1.0 \%$. During relatively deep-lake intervals, variability in the $\delta^{13} \mathrm{C}$ value of TOC cannot be attributed to allochthonous sources of carbon because the amount of particulate organic carbon (POC) in the Walker River is small $(4 \%)$ relative to the amount of DIC entering the lake (Table 4). Part of the variability in the $\delta^{13} \mathrm{C}$ value of TOC probably results from selective decomposition of POC as it falls through the water column and as the material accumulates at the bottom of the lake. Fine particles of phytoplankton and zooplankton decompose at a rate of about $1 \%$ /day (Saunders, 1976). Residual organic material undergoes aerobic decomposition by microscopic organisms, fungi, and bacteria. As oxygen becomes depleted in the interstitial water, anaerobic decomposition becomes the predominant process. The quantity and type of organic matter preserved in Walker Lake sediments depend on the bulk rate of sedimentation and the resistance of the organic material to decomposition (Meyers and Benson, 1987). 
Stable-isotope indications of lake-level variations in the Walker Lake subbasin for the past 5000 years

Interpretation of the stable-isotope values of unrecrystallized carbonates in WLC84-8 (Fig.12b, $c, d, f)$ indicates several general trends in lake level:

(1) Between $12.0-10.9 \mathrm{~m}(5300-4800$ yr B.P.), Walker Lake was shallow.

(2) Between $10.9-10.6 \mathrm{~m}$ (4800-4700 yr B.P.), Walker Lake was rising.

(3) Between 10.6-10.4 m (4700-4630 yr B.P.), the level of Walker Lake was approaching a steadystate condition.

(4) Between 10.4-5.2 m (4630-2900 yr B.P.), Walker Lake maintained a more-or-less steadystate level.

(5) Between $5.0-4.6 \mathrm{~m}$ (2840-2700 yr B.P.), Walker Lake was declining.

(6) Between 4.6-4.0 m (2700-2310 yr B.P.), Walker Lake was shallow.

(7) Between 4.0-3.6 m (2310-1950 yr B.P.), Walker Lake was rising.

(8) Between 3.6-2.0 $\pm \mathrm{m}$ (1950-900 yr B.P.), Walker Lake was declining.

(9) Between $2.0 \pm-0.3 \mathrm{~m}(840-150 \mathrm{yr}$ B.P.), the stable-isotope data are more difficult to interpret. The $\delta^{18} \mathrm{O}$ and the $\delta^{13} \mathrm{C}$ values of the TIC fraction indicate rising lake levels beginning at $2.0 \mathrm{~m}(840$ yr B.P.). The $\delta^{13} \mathrm{C}$ data for the TIC fraction also appears to indicate that the lake stabilized or fell at $1.5 \mathrm{~m} \mathrm{(630} \mathrm{yr} \mathrm{B.P.)} \mathrm{and} \mathrm{then} \mathrm{rose} \mathrm{again.} \mathrm{The}$ $\delta^{13} \mathrm{C}$ value of $L$. ceriotuberosa is similar to that of the TIC fraction but there are too few data points to rely solely on this parameter.

(10) Between 0.3-0.0 m (130-0 yr B.P.), the increasing $\delta^{18} \mathrm{O}$ and the $\delta^{13} \mathrm{C}$ values of L. ceriotuberosa indicate a rapid decline in lake level.

Superimposed on these general trends in the $\delta^{18} \mathrm{O}$ and the $\delta^{13} \mathrm{C}$ values of unrecrystallized carbonates are several minor variations (Fig.12b, c, $\mathrm{d}$, e). Depletions in the $\delta^{18} \mathrm{O}$ and the $\delta^{13} \mathrm{C}$ values of the carbonates occur at the following depths (times) in WLC84-8: $9.5 \mathrm{~m}$ (4330 yr B.P.), $9.2 \mathrm{~m}$ (4230 yr B.P.), $8.7 \mathrm{~m}$ (4070 yr B.P.), $8.2 \mathrm{~m}(3900$ yr B.P.), $5.0 \mathrm{~m}$ (2840 yr B.P.), $2.6 \mathrm{~m}$ (1090 yr B.P.),
$1.8 \mathrm{~m}$ (760 yr B.P.), $1.2 \mathrm{~m}$ (510 yr B.P.), and $0.6 \mathrm{~m}$ (250 yr B.P.). These depletions are interpreted to indicate relatively rapid rises in lake level and are included in the stable-isotope based interpretation of the lake-level record summarized schematically in Fig.16c. The general trends in lake level indicated by the stable-isotope data are consistent with trends in lake level indicated by carbonate mineralogy and chemistry (Figs.11 and 12).

\section{Grain-size data for WLC84-8}

Grain-size data for WLC84-8 were taken from Yount and Quimby (1990). During shallow-lake intervals, fine-grained clays and silts were deposited at the WLC84-8 site (Fig.15). The silt fraction and mean grain size rapidly increased after the shallow-lake intervals (Fig.15a, c, d). Between $10.2-4.8 \mathrm{~m}$, the amounts of silt and sand gradually increased. Between 2.5-0.2 m, the amounts of silt and sand are variable, but a tendency exists for silt to decrease with decreasing depth. In the upper $5.0 \mathrm{~m}$ of WLC84-8, the percentage of sand is small and highly variable.

We hypothesize that increase in the relative amount of clay deposited during shallow-lake intervals (Fig.15b) resulted from deflational transport of fine-grained material from newly exposed lake sediment to the WLC84-8 site, and from reduced competence of the Walker River. Increase in clay content in the upper $0.2 \mathrm{~m}$ of WLC84-8 is not a natural phenomenon, but is due to upstream trapping of coarse-grained material by reservoirs located on the Walker River (Fig.2). The transition to coarse-grained material between $10.9-10.2 \mathrm{~m}$ and $3.8-2.5 \mathrm{~m}$ (Fig. $15 \mathrm{c}, \mathrm{d}$ ) is interpreted to indicate rising lake level in the Walker Lake subbasin. The increase in silt content at $11 \mathrm{~m}$ in the lower shallow lake interval indicates that Walker Lake may have been relatively deep 5000 yr B.P.

Depth intervals that represent relatively deep lakes (Fig.15a, 10.2-4.8 m and 2.5-0.2 m) contain several second-order peaks in grain size (e.g., peaks centered at $2.4 \mathrm{~m}[\sim 1000 \mathrm{yr}$ B.P.], $1.2 \mathrm{~m}[\sim 500$ yr B.P.], and $0.4 \mathrm{~m}[\sim 170 \mathrm{yr}$ B.P.] in the upper deep-lake interval). The grain-size peak centered at $2.4 \mathrm{~m}$ is coincident with a tree-stump-based lowstand of Walker Lake (Fig.8b); however, the 


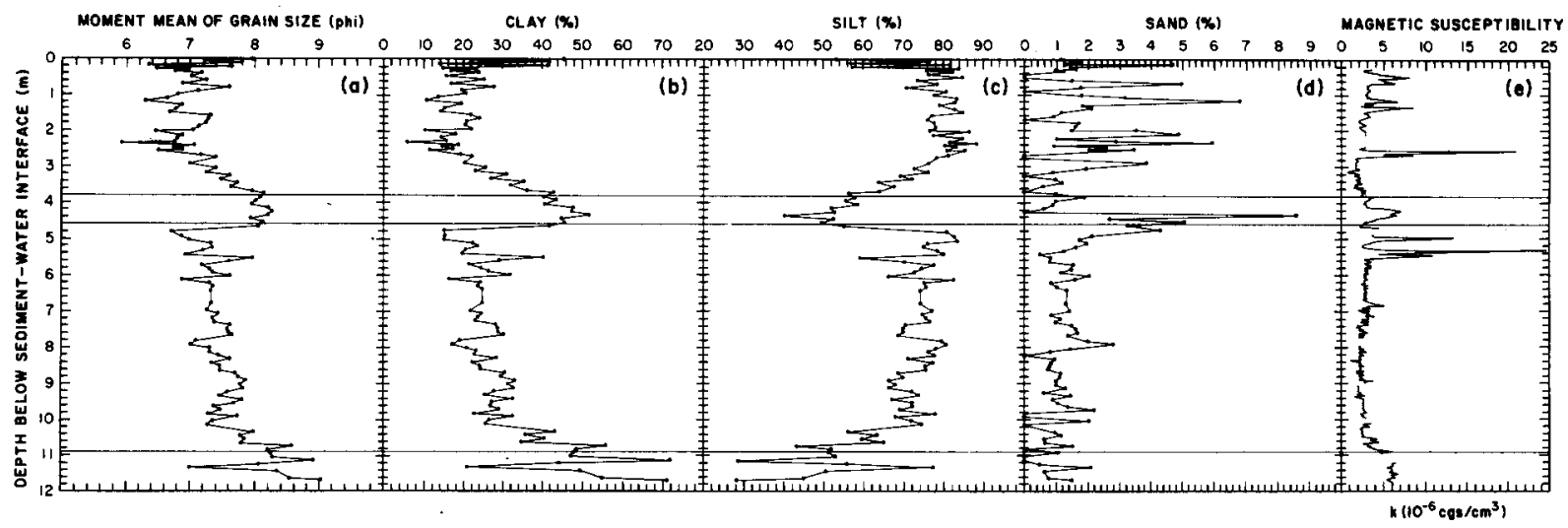

Fig.15. Grain-size and magnetic-susceptibility data for WLC84-8 (Grain-size data taken from Yount and Quimby, 1990; magnetic susceptibility data are from W. Witte, pers. comm., 1990).

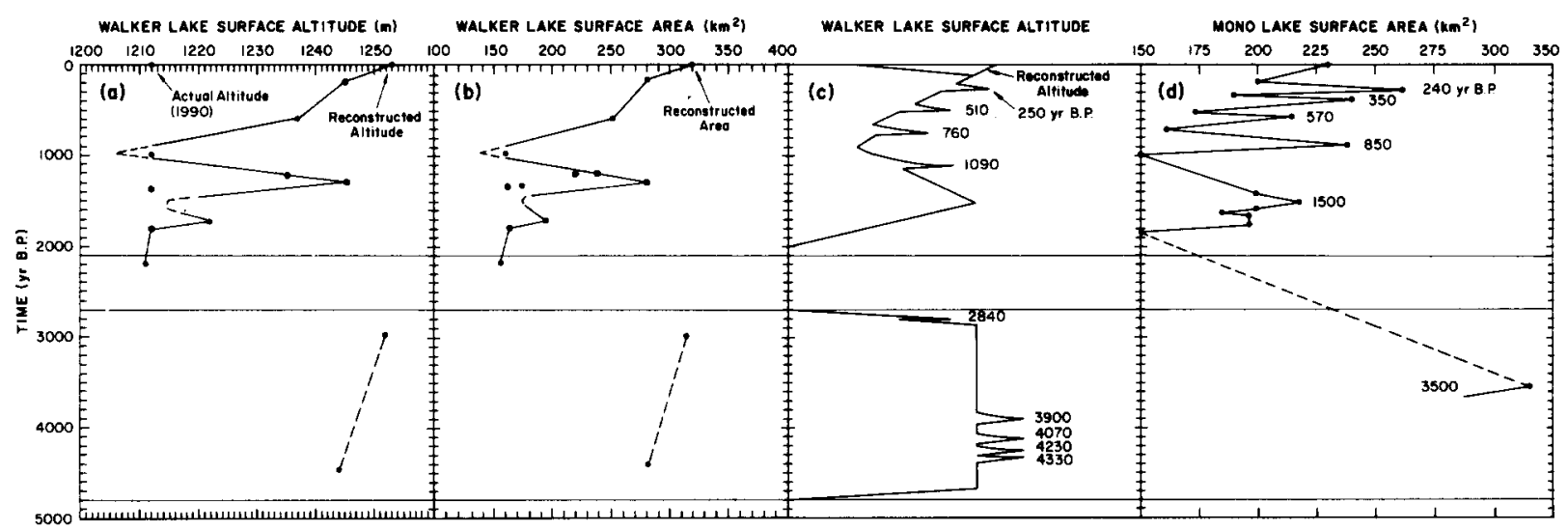

Fig.16. Comparison of selected lake-size variations for the past $\leq 5000$ radiocarbon years [(a) lake surface altitude reconstructed using tufa and rooted tree-stump radicarbon ages; (b) lake surface area reconstructed using altitudes from (a) and surface area/ altitude data from Benson and Mifflin (1986); (c) lake surface altitude reconstucted using $\delta^{13} \mathrm{C}$ and $\delta^{18} \mathrm{O}$ data from WLC84-8; (d) adapted from Stine, 1990].

grain-size maximum centered at $1.2 \mathrm{~m}$ is roughly coincident with a highstand of Walker Lake (Fig.8b), illustrating the difficulty in using grainsize data to estimate change in lake level.

Variation in the amount of sand-size material between 3.8 and $0.0 \mathrm{~m}$ (Fig.15d) parallels variation in the abundance of F brevistriata (Fig. $7 \mathrm{~g}$ ). If it is assumed that the introduction of sand-size material is due either to (1) proximity of the core site to the delta region (decreasing lake level) or to (2) increased competence of the Walker River (increasing lake level), the observed covariance of peaks in the F. brevistriata and sand-size populations support the hypothesis that F. brevistriata was transported from its shallow-freshwater habitat to the WLC84-8 site by flood events. However, it is also possible that the covariance of $F$. brevistriata and sand-size material resulted from turbidite activity.

\section{Magnetic susceptibility data for WLC84-8}

Sediments deposited during shallow-lake intervals have about twice the mean magnetic susceptibility of other WLC84-8 sediments (Fig.15e). This increase in susceptibility is consistent with reduced discharge of the Walker River; i.e., during low-flow conditions, less calcium was available to form paramagnetic calcium carbonate (Figs.11 and 13), which dilutes the magnetic, detrital-silicate component of the sediment. In addition, desiccation of Walker Lake probably occurred 
during the shallow-lake intervals. This would have led to decreased sediment porosity, causing an apparent increase in the bulk-magnetic susceptibility.

Five double peaks in magnetic susceptibility occur within the upper $6 \mathrm{~m}$ of WLC84-8 (Fig.15e). Troughs in susceptibility between double peaks at $2.6 \mathrm{~m}(\sim 1100$ yr B.P.), $1.2 \mathrm{~m}(\sim 500$ yr B.P.), and $0.6 \mathrm{~m}(\sim 250 \mathrm{yr}$ B.P. $)$ coincide with troughs (depleted values) in the $\delta^{18} \mathrm{O}$ and $\delta^{13} \mathrm{C}$ values of the TIC fraction (Fig.12b and d). Troughs in susceptibility at $5.5 \mathrm{~m}(\sim 3000$ yr B.P. $)$ and at $4.8 \mathrm{~m}(\sim 2770$ yr B.P. $)$ do not coincide with depleted values of $\delta^{18} \mathrm{O}$ and $\delta^{13} \mathrm{C}$. The lack of coincidence may be due to recrystallization of the TIC fraction.

Peaks in magnetic susceptibility are interpreted to indicate proximity of the WLC84-8 site to the delta or to shore regions that are both sources of magnetic-detrital silicates. Proximity to these sources indicates a decrease in lake level. Therefore, troughs in magnetic susceptibility together with depletions in $\delta^{18} \mathrm{O}$ and $\delta^{13} \mathrm{C}$ values are interpreted to indicate increases in lake level.

\section{Cause of the shallow-lake intervals}

Both WLC84-8 and WLC76-G were taken in water depths of $\sim 34 \mathrm{~m}$ (Benson, 1988). Within part of the upper shallow-lake interval (e.g., $3.1-3.8 \mathrm{~m}$ of WLC76-G; Fig.5 of Bradbury, 1987), diatoms are absent or poorly preserved. This, together with the presence of Ruppia pollen (see p. 197), indicates water depths of $<1 \mathrm{~m}$. Using the bathymetric map of Rush (1970), the surface area of the <1-m-deep Walker Lake was calculated to be $<35 \mathrm{~km}^{2}$ $(<11 \%$ of its reconstructed mean-historical surface area of $320 \mathrm{~km}^{2}$; Milne, 1987). Everett and Rush (1967) estimated that $0.0185 \mathrm{~km}^{3}$ of water reaches Walker Lake as annual runoff from the surrounding mountains. If, during the upper shallow-lake period, the mean-annual precipitation, evaporation, and runoff rates were similar to those of the historical period, a lake with a $17 \mathrm{~km}^{2}$ surface area would have existed in the Walker Lake subbasin if input from the Walker River ceased. These calculations indicate that a shallow ephemeral lake could have been maintained in the Walker Lake subbasin despite diversion of the Walker River to the Carson Desert subbasin.

In the Walker Lake and Pyramid Lake subbasins, the climate of watershed areas located in bordering mountain ranges controls fluid input to the subbasins (Fig.1). Benson and Paillet (1989) have argued that desiccations of Walker Lake since $21,000 \mathrm{yr}$ B.P. resulted from diversion of the Walker River. Their argument was based on two observations: Pyramid Lake did not fall below $1153 \mathrm{~m}$ during the past 21,000 yr (Benson and Thompson, 1987b) and historical, reconstructed, mean-annual discharges of the Walker and Truckee Rivers are well correlated $\left(R^{2}=0.76\right)$ (Fig. 17). Because present-day discharges of the two rivers are well correlated, it is reasonable to assume that their past discharges were also well correlated. If Pyramid Lake did not desiccate during the past $21,000 \mathrm{yr}$, then discharge of the Truckee River did not cease for any significant amount of time during the same time period. Therefore, it follows that discharge of the Walker River also did not cease during the past $21,000 \mathrm{yr}$.

The types of fish that inhabited Pyramid and Walker Lakes in 1940 also indicate that desiccations of Walker Lake since $21,000 \mathrm{yr}$ B.P. were

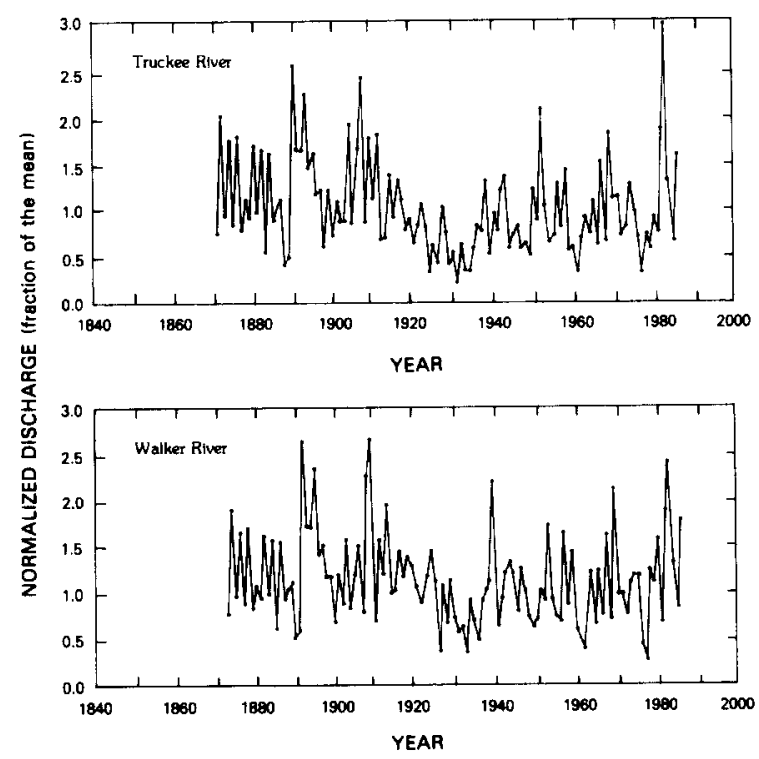

Fig. 17. Reconstructed streamflow-discharge variations for the Truckee and Walker Rivers between 1871 and 1985 (adapted from Milne, 1987). 
caused by diversion of the Walker River. Lahontan cutthroat trout (Salmo clarki hanshawi) inhabit lakes and streams; but in order to spawn, lakedwelling Lahontan cutthroat must ascend the river that discharges into the lake (La Rivers, 1962). The cui-ui (Chasmiste cujus), a member of the sucker family, lives only in lakes and is known only from Pyramid and Winnemucca Lakes (the latter is now dry). It prefers to spawn in the lower reaches of the Truckee River, but it has been observed to spawn at the periphery of Pyramid Lake (Sigler et al., 1985).

Prior to 1850, Lahontan cutthroat inhabited the Truckee and Walker Rivers and Pyramid and Walker Lakes (La Rivers, 1962). In 1875, a large dam which closed the upper Truckee River to Lahontan cutthroat was built on the Truckee River at Verdi, Nevada. In 1905, a diversion dam was built at Derby, Nevada. The Derby Dam closed the middle reach of the Truckee River to Lahontan cutthroat and diverted about one-half of the Truckee River's flow out of the Pyramid Lake subbasin (Townley, 1980). By $\sim 1930$, Pyramid Lake had fallen to $1170 \mathrm{~m}$ and not enough water reached Pyramid Lake to allow Lahontan cutthroat to enter the river. Because the existence of the Lahontan cutthroat in Pyramid Lake was dependent on the ability of the fish to spawn in the Truckee River, by 1940 , the Lahontan cutthroat were gone from the Lake (La Rivers, 1962).

During the last highstand of Lake Lahontan ( 14,500 yr B.P.), the Walker and Pyramid Lake subbasins were connectd (Benson and Thompson, 1987a). At that time, the Lahontan cutthroat and cui-ui coexisted throughout the seven subbasins of Lake Lahontan. The persistence of a spawning populations of Lahontan cutthroat and cui-ui in Pyramid Lake until $\sim 1930$ indicates the lake did not fall below the 1170-m level for any extended period of time ( $>30 \mathrm{yr}$ ) during the past $21,000 \mathrm{yr}$. The presence of Lahontan cutthroat and absence of cui-ui in Walker Lake during the late 1800 s (P. Wagner, pers. comm., 1990) indicates that posthighstand desiccations of Walker Lake were caused by diversion of the Walker River. When the river diverted to the Carson River drainage, the Lahontan cutthroat were able to live in the river, but the cui-ui, a lake-dwelling species, died. When the river diverted back to the Walker Lake subbasin, the Lahontan cutthroat reentered Walker Lake.

\section{Comparison of the Walker Lake-level record with the lake-level record of Mono Lake}

Reconstructed records of lake-level change for the Pyramid Lake/Winnemucca Lake and Mono Lake basins indicate a high degree of correspondence since 1910 (fig. 22 in Milne, 1987). In this section, the late-Holocene records of lake-level change that occurred in these basins are compared.

The lake-level record (relative scale) for Walker Lake constructed from stable-isotope data for inorganic carbonates (Fig.16c) is similar to the lake-level and surface-area records for Walker Lake constructed using tufa and tree-stump data (Fig.16a, b). Both lake-level records indicate relatively high lake levels between $4800-2700$ yr B.P. and within the last $300 \mathrm{yr}$. Both records also indicate depressions in lake level $\sim 2000$ and $\sim 1000$ yr B.P. Decline in lake level prior to the upper shallow-lake interval appears to have begun $\sim 3000$ yr B.P. and recovery from the shallow-lake interval may have begun as early as $\sim 2000$ yr B.P.

The Mono Lake surface-area record constructed by Stine, 1990 (Fig. 16d) also indicates the existence of relatively large lakes in the Mono Lake basin prior to $2700 \mathrm{yr}$ B.P. and within the last $300 \mathrm{yr}$. In addition, a relatively shallow lake existed at $\sim 2000$ and $\sim 1000$ yr B.P. Between $1600-200$ yr B.P., Mono Lake experienced five peaks in lake size. The Walker Lake stable-isotope record of lake-size change is somewhat similar to the Mono Lake record for this time, although most changes in lake size cannot be demonstrated to have occurred synchronously. The asynchroneity may be due to the approximate nature of ages assigned to the Walker Lake record or it may be due to the discontinuous nature of both records. The Mono Lake record does not indicate desiccation between 2700-2100 yr B.P. but it does indicate that Mono Lake achieved a level as low as any attained in late Holocene time.

\section{Summary and conclusions}

All organic and inorganic proxy indicators of lake size discussed in this paper were found useful 
in determining the presence and timing of extremely shallow-lake intervals in the Walker Lake subbasin. However, none of the indicators could be used to determine the cause of the shallow-lake intervals (river diversion or climatic change). The types of fish present in Pyramid and Walker Lakes prior to 1940 were used to demonstrate that the shallow-lake (desiccation) intervals were caused by diversion of the Walker River to the Carson River drainage. The lower (oldest) shallow-lake interval recorded in sediments of WLC 84-8 began prior to $5300 \mathrm{yr}$ B.P. and ended 4800 yr B.P. The upper (youngest) shallowlake interval occurred between $2700-2100$ yr B.P. A calculation, using present-day hydrologic data, indicates that shallow lakes would have intermittently existed in the Walker Lake subbasin despite diversion of the Walker River. This calculation is in agreement with the presence of abundant Ruppia pollen at $\sim 3.8 \mathrm{~m}$ in WLC $84-8$ that indicated the presence of a shallow ( $<1 \mathrm{~m}$ deep) saline lake.

Changes in carbonate mineralogy and diatom taxa that occurred between the two shallow-lake intervals resulted from change in the hydrologic balance of the Walker Lake subbasin combined with the progressive chemical evolution (increasing salinity) of Walker Lake. While palynomorphs were useful in delimiting shallow-lake intervals, palynological data were much less useful in delimiting moderate- and deep-water intervals.

Calcium carbonate accumulation in the sediments of Walker Lake appears to result from the homogeneous precipitation of carbonate whitings. Today (1957-1980), carbonate precipitation occurs in the epilimnion of the lake during the late summer/early autumn. The magnesium contents of calcites in WLC84-8 progressively increase after shallow-lake intervals until they contain $\sim 10$ mole $\% \mathrm{MgCO}_{3}$; then monohydrocalcite occurs. Lowmagnesium calcites found between $12.0-10.9 \mathrm{~m}$ and $7.4-3.8 \mathrm{~m}$ in WLC $84-8$ probably formed by recrystallization of metastable monohydrocalcite in a magnesium-depleted pore fluid. This recrystallization reset the magnesium, $\delta^{18} \mathrm{O}$, and $\delta^{13} \mathrm{C}$ values of the carbonate minerals, limiting their usefulness in recreating the chemical and isotopic history of Walker Lake.

The stable isotopes of oxygen and carbon are very useful in determining the direction of change in lake size. Changes in $\delta^{18} \mathrm{O}$ in a closed-basin lake indicate the relative importance of evaporative removal of isotopically depleted water vapor from the lake relative to the input of isotopically depleted streamflow discharge. An increase in volume is accompanied by a depletion in the ${ }^{18} \mathrm{O}$ value of lake water and a decrease in volume is accompanied by enrichment in ${ }^{18} \mathrm{O}$. However, the magnitude of the $\delta^{18} \mathrm{O}$ value of water in a closedbasin lake (or the carbonate precipitated from the lake) cannot be used to determine the exact volume of the lake since the $\delta^{18} \mathrm{O}$ value is dependent on the rate of lake-level change.

Fractionation of ${ }^{18} \mathrm{O}$ between a carbonate precipitate and lake water is a function of: (1) mineralogy of the precipitate, (2) chemistry of the precipitate, (3) temperature of precipitation, and (4) the ${ }^{18} \mathrm{O}$ content of lake water. When reconstructing the $\delta^{18} \mathrm{O}$ history of a lake, it is preferable to analyze a stable form of calcium carbonate that forms below the thermocline. This minimizes the possibility of recrystallization and the temperature dependency of fractionation. Deep-water benthic ostracodes are ideal for this purpose.

The $\delta^{13} \mathrm{C}$ value of water in a closed-basin lake is a function of: (1) the $\delta^{13} \mathrm{C}$ value of a streamflow discharge, (2) storage of organic and inorganic forms of carbon beneath the sediment-water interface, (3) temporary loss of carbon through increased productivity, and (4) exchange of carbon across the air-water interface. In the Walker Lake subbasin, the $-16 \%$ value of river water indicates that the decay of $\mathrm{C} 3$ plant material in the soil zone influences the $\delta^{13} \mathrm{C}$ value of water reaching Walker Lake.

The DIC reservoir in Walker Lake becomes essentially infinite with respect to annual storage of TOC and TIC, as well as seasonal changes in productivity, within a few hundred years after the Walker River diverts back to the Walker Lake subbasin. This indicates that depletions in $\delta^{13} \mathrm{C}$ values of carbonates precipitated from Walker Lake resulted from extreme discharge events. The magnitude of some of the depletions indicates the occurrence of successive years of above-normal streamflow discharge. These conclusions are consistent with the observation that there exists a 
significant degree of correspondence in trends and peak-to-peak variabilities in the $\delta^{13} \mathrm{C}$ and $\delta^{18} \mathrm{O}$ values of $L$. ceriotuberosa and in the $\delta^{13} \mathrm{C}$ and $\delta^{18} \mathrm{O}$ values of the TIC fraction in sediments of WLC84-8. However, L. ceriotuberosa exerts a strong vital effect on its own $\delta^{13} \mathrm{C}$ value. This implies that the temperature-dependent fractionation factors for the system $\mathrm{CO}_{3}^{2-}-\mathrm{CaCO}_{3}$ (s) cannot be used to determine the $\delta^{13} \mathrm{C}$ value of lake water from the $\delta^{13} \mathrm{C}$ value of $L$. ceriotuberosa.

Whereas there is a substantial amount of peakto-peak correspondence in the $\delta^{13} \mathrm{C}$ records for TOC and TIC in WLC84-8, there is a lack of correspondence in the magnitude of long-term trends in the $\delta^{13} \mathrm{C}$ values of TOC and TIC. This lack of correspondence probably results from selective decomposition of POC as it falls through the water column and during the residence time of POC in the upper $20 \mathrm{~cm}$ of the sediment column:

Increase in the relative amount of clay deposited during shallow-lake intervals is hypothesized to have resulted from deflational transport of finegrained material from newly exposed lake sediment to the WLC84-8 site and from reduced competence of the Walker River. The transition to coarsegrained material between $10.9-10.2 \mathrm{~m}$ and 3.8-2.5 $\mathrm{m}$ in WLC84-8 is interpreted to indicate rising lake levels in the Walker Lake subbasin. The increase in silt content at $11.3 \mathrm{~m}$ in the lower shallow-lake interval indicates that Walker Lake may have been relatively deep 5000 yr B.P. The observed covariance of peaks in the $F$. brevistriata and sandsize populations support the hypothesis that F. brevistriata was transported from its shallowfreshwater habitat to the WLC84-8 site by flood events.

The schematic lake-level record for Walker Lake constructed from stable-isotope data is similar to the lake-level and surface-area records constructed using tufa and tree-stump data. Both records indicate relatively high levels between $4800-2700 \mathrm{yr}$ B.P, at $1250 \mathrm{yr}$ B.P., and within the last $300 \mathrm{yr}$. Both records also indicate substantial declines in lake level $\sim 2000$ and $\sim 1000$ yr B.P. The Mono Lake surface-area record also indicates the existence of relatively large lakes in the Mono Lake basin prior to $2700 \mathrm{yr}$ B.P. and within the last 300 yr. In addition, relatively shallow lakes existed at $\sim 2000$ and $\sim 1000$ yr B.P. Between $1600-200 \mathrm{yr}$ B.P., Mono Lake experienced five peaks in lake size. The Mono Lake record of surface area change is somewhat similar to the Walker Lake stableisotope record of lake-size variation for this time; however, most changes in lake size cannot be demonstrated to have occurred synchronously.

\section{Acknowledgments}

The authors acknowledge discussions with $\mathrm{W}$. Broecker and R. Wanninkhof at the LamontDoherty Geological Observatory, with J. Quade of the University of Utah, with D. Galat of the U.S. Fish and Wildlife Service, and with I. Friedman, J. Bradbury, R. Thompson, and D. Thorstenson of the U.S. Geological Survey. R. Fifer of Brown University and K. C. Lohman of the University of Michigan performed the isotopic analyses. Special thanks are due to R. Thompson of the U.S. Geological Survey and W. Witte of the Lamont-Doherty Geological Observatory for use of their unpublished data and to Y. Lao of the Lamont-Doherty Geological Observatory who performed four of the radiocarbon analyses. T. Cerling of the University of Utah and S. Hostetler and F. Paillet of the U.S. Geological Survey provided helpful reviews of the paper.

\section{References}

Benson, L. V., 1988. Preliminary paleolimnologic data for the Walker Lake subbasin, Caifornia and Nevada. U.S. Geol. Surv. Water-Resour. Invest. Rep., 87-4258, 50 pp.

Benson, L. V. and Leach, D. L., 1979. Uranium transport in the Walker River basin. Geochem. Explor.; 11: 227-248.

Benson, L. V. and Mifflin, M. D., 1986. Reconnaissance bathymetry of basins occupied by Pleistocene Lake Lahontan, Nevada and California: U.S. Geol. Surv. Water-Resour. Invest. Rep., 85-4262, 14 pp.

Benson, L. V. and Paillet, F. L., 1989. The use of total lakesurface area as an indicator of climatic change: Examples from the Lahontan basin. Quat. Res., 32: 262-275.

Benson, L. V. and Spencer, R. J., 1983. A hydrochemical reconaissance of the Walker River basin, California and Nevada. U.S. Geol. Surv. Open-File Rep., 83-740, 53 pp.

Benson, L. V. and Thompson, R. S., 1987a. Lake-level variation in the Lahontan Basin for the past 50,000 years. Quat. Res., 28: 69-85.

Benson, L. V. and Thompson, R. S., 1987b. The Physical Record of Lakes in the Great Basin. In: W. F. Ruddiman 
and H. E. Wright Jr. (Editors), North America and Adjacent Oceans During the Last Deglaciation (Geology of North America, K-3). Geol. Soc. Am., Boulder, Colo., pp. 241-260.

Bradbury, J. P., 1987. Late Holocene diatom paleolimnology of Walker Lake, Nevada, Arch. Hydrobiol., Suppl. 79, Monogr. Beitr., 1: 1-27.

Bradbury, J. P., Forester, R. M. and Thompson, R. S., 1989. Late Quaternary paleolimnology of Walker Lake, Nevada. J. Paleolimnol., 1: 249-267.

Broecker, W. S. and Walton, A. F., 1959. The geochemistry of ${ }^{14} \mathrm{C}$ in freshwater systems. Geochim. Cosmochim. Acta, 16: $15-38$.

Cerling, T. E., 1984. The stable isotope composition of modern soil carbonate and its relationship to climate. Earth Planet. Sci. Lett., 71: 229-240.

Chivas, A. R., De Deckker, P. and Shelley, J. M. G., 1986. Magnesium content of non-marine ostracod shells: a new palaeosalinometer and palaeothermometer. Palaeogeogr., Palaeocimatol., Palaeoecol., 54: 43-61.

Davis, J. O., 1982. Bits and pieces; The last 35,000 years in the Lahontan area. In: D. B. Madsen and J. F. O'Connell (Editors), Man and Environment in the Great Basin. Soc. Am. Archeol. Pap., 2: 53-75.

Dever, L., Fontes, J. and Riche, G., 1987. Isotopic approach to calcite dissolution and precipitation in soils under semiarid conditions. Chem. Geol., 66: 307-314.

Everett, D. E. and Rush, F. E., 1967. A brief appraisal of the water resources of the Walker Lake area, Mineral, Lyon, and Churchill Counties, Nevada. Nev. Dep. Conserv. Nat. Resour. Water Resour. Reconn. Ser. Rep., 40, 44 pp.

Friedman, I. F. and O'Neil, J. R., 1977. Compilation of stable isotope fractionation factors of geochemical interest. In: $M$. Fleischer (Editor), Data of Geochemistry. Sixth Edition. U.S. Geol. Surv. Prof. Pap., 440-KK.

Galat, D. L., 1986. Organic carbon flux to a large salt lake: Pyramid Lake, Nevada, USA. Int. Rev. Ges. Hydrobiol, 71:621-654.

Galat, D. L. and Jacobsen, R. L., 1985. Recurrent aragonite precipitation in saline-alkaline Pyramid Lake, Nevada. Arch. Hydrobiol., 105: 137-159.

Galat, D. L. and Verdin, J. P., 1988. Magnitude of blue-green algal blooms in a saline desert lake evaluated by remote sensing evidence for nitrogen control. Can. J. Fish. Aquat. Sci., 45: 1959-1967.

Goldsmith, J. R. and Graf, D. C., 1958. Relation between lattice constants and compositions of $\mathrm{Ca}-\mathrm{Mg}$ carbonates. Am. Mineral., 43: 84-101.

Harding, S. T., 1965. Recent variations in the water supply of the western Great Basin. Univ. Calif. Arch. Ser. Rep., 16, $226 \mathrm{pp}$.

Hull, H. and Turnbull, A. G., 1973. A thermochemical study of monohydrocalcite. Geochim. Cosmochim. Acta, 37: 685-694.

Keeling, C. D., 1961. The concentration and atmospheric abundances of atmospheric carbon dioxide in rural and marine air. Geochim. Cosmochim. Acta, 24: 277-298.

Kelts, K. and Hsu, K. J., 1978. Freshwater carbonate sedimentation. In: A. Lerman (Editor), Lakes - Chemistry, Geology, Physics, Springer, New York, NY, pp. 295-323.

King, G. Q., 1978. The late Quaternary history of Adrian
Valley, Lyon County, Nevada. Thesis. Univ. Utah, Salt Lake City, 88 pp.

Koch, D. L., Cooper, J. C., Lider, E. L., Jacobson, R. L. and Spencer, R. J., 1979. Investigations of Walker Lake, Nevada: dynamic ecological relationships. Desert Res. Inst. Publ., $50010,191 \mathrm{pp}$.

La Rivers, I., 1962. Fishes and Fisheries of Nevada. Nev. State Fish Game, 782 pp.

Lao, Y. and Benson, L. V., 1988. Uranium-series age estimates and paleoclimatic significance of Pleistocene tufas from the Lahontan basin, California and Nevada. Quat. Res., 30: 165-176.

Meyers, P. A. and Benson, L. V., 1987. Sedimentary biomarker and isotopic indicators of the paleoclimatic history of the Walker Lake basin, western Nevada. Adv. Org. Geochem., 13: 807-813.

Milne, W., 1987. A comparison of reconstructed lake-level records since the mid-1800's of some Great Basin lakes. Thesis. Colorado School of Mines, Golden, 207 pp.

Oomori, T., Kaneshima, H., Maezato, Y. and Kitano, Y., 1987. Distribution coefficient of $\mathrm{Mg}^{2+}$ ions between calcite and solution at $10-50^{\circ} \mathrm{C}$. Mar. Chem., 20: 327-336.

Peng, T.-H. and Broecker, W. S., 1980. Gas exchange rates for three closed-basin lakes. Limnol. Oceanogr., 25: 789-796.

Plummer, L. N., Jones, B. F. and Truesdell, A. H., 1976. WATEQF - A FORTRAN version of WATEQ, a computer program for calculating chemical equilibrium of natural waters. U.S. Geol. Surv. Water-Resour. Invest. Rep., 76-13, $61 \mathrm{pp}$.

Quade, J., Cerling, T. E. and Bowman, J. R., 1989. Systematic variations in the carbon and oxygen isotopic composition of pedogenic carbonate along elevation transects in the southern Great Basin, United States. Geol. Soc. Am. Bull, 101: 464-475.

Rush, F. E., 1970. Hydrologic regimen of Walker Lake, Mineral County, Nevada. State Nev., Dep. Conserv. Natur. Resour. Rep., 21, Hydrol. Invest. Atlas HA-415, 1 p.

Russell, I. C., 1885. Geological history of Lake Lahontan, a Quaternary lake of northwestern Nevada. U.S. Geol. Surv. Monogr., 11, 287 pp.

Saunders, G. W., 1976. Decomposition in freshwater. In: J. M. Anderson and A. Macfadyen (Editors), The Role of Terrestrial and Aquatic Organisms in Decomposition Processes. In: 17th Symp. Br. Ecol. Soc. Blackwell, Oxford, pp. 341-373.

Sigler, W. F., Vigg, S. and Bres, M., 1985. Life history of the Cui-ui, Chasmiste cujus cope. In: Pyramid Lake, Nevada: A review. Great Basin Nat., 45: 571-603.

Spencer, R. J., 1977. Silicate and carbonate sediment-water relationships in Walker Lake, Nevada. Thesis. Univ. Nevada, Reno, 98 pp.

Stine, S., 1990. Late Holocene fluctuations of Mono Lake, eastern California. In: P. A. Meyers and L. V. Benson (Editors), Paleoclimates: the Record from Lakes, Ocean and Land. Palaeogeogr., Palaeoclimatol., Palaeoecol., 78: 333-381.

Tarutani, T., Clayton, R. N. and Mayeda, T. K., 1969. The effect of polymorphism and magnesium substitution on oxy- 
gen isotope fractionation between calcium carbonate and water. Geochim. Cosmochim. Acta, 33: 987-996.

Townley, J. M., 1980. The Truckee basin fishery, 1844-1944. Desert Res. Inst. Publ., 43008, 88 pp.

Turpen, J. B. and Angell, R. W., 1971. Aspects of molting and calcification in the ostracod Heterocypris. Biol. Bull., 140: 331-338.

U.S. Geol. Surv., 1960. Compilation of records of surface water of the United States through September 1950; Part 10, the Great Basin. U.S. Geol. Surv. Water-Supply Pap., 1314, $485 \mathrm{pp}$.

U.S. Geol. Surv., 1963. Compilation of records of surface water of the United States, October 1950 to September 1960; Part
10, the Great Basin. U.S. Geol. Surv. Water-Supply Pap., $1734,318 \mathrm{pp}$.

U.S. Geol. Surv., 1961-1987. Water Resources Data for Nevada. U.S. Geol. Surv. Water-Data Rep. Ser., Annu. Vol.

Veizer, J. and Hoefs, J., 1976. The nature of ${ }^{18} \mathrm{O} /{ }^{16} \mathrm{O}$ and ${ }^{13} \mathrm{C} /$ ${ }^{12} \mathrm{C}$ secular trends in sedimentary carbonate rocks. Geochim. Cosmochim. Acta., 40: 1387-1395.

Yang, I.-C., 1988. Radiocarbon Dates V. Radiocarbon, 30: $4 \mathrm{I}-60$.

Yount, J. C. and Quimby, M. F., 1990. Grain-size data from four cores from Walker Lake, Nevada. U.S. Geol. Surv. Open-File Rep., 88-436, 79 pp. 